\title{
PALAEOENVIRONMENTAL CONTEXTS FOR MICROBIAL COMMUNITIES FROM Fe-Mn CRUSTS OF MIDDLE-UPPER JURASSIC HARDGROUNDS (BETIC-RIFIAN CORDILLERA)
}

\author{
Matías REOLID \\ Departamento de Geología, Universidad de Jaén, Campus Las Lagunillas s/n, \\ 23071, Jaén, Spain
}

Reolid, M. 2011. Palaeoenvironmental contexts for microbial communities from Fe-Mn crusts of Middle-Upper Jurassic hardgrounds (Betic-Rifian Cordillera). [Contextos paleoambientales de las comunidades microbianas de las costras ferromanganesíferas de los hardgrounds del Jurásico Medio-Superior (Cordillera Bético-Rifeña).] Revista Española de Paleontología, 26 (2), 135-160. ISSN 0213-6937.

\begin{abstract}
The Middle-Upper Jurassic transition within the External Subbetic (Betic Cordillera) and the Jbel Moussa Group (Rifian Calcareous Chain) is characterised by numerous stratigraphic breaks recorded as palaeoreliefs, omission surfaces and hardgrounds. The features and number of unconformities vary depending on the domain studied and the tectonic unit. One common characteristic is the presence of microbial Fe-Mn crusts and Mn crusts. Three different contexts of microbially mediated Fe-Mn crusts can be distinguished: a) hydrogenetic surficial Fe-Mn crusts and macro-oncoids, b) hydrogenetic cryptic Fe-Mn crusts, and c) hydrothermal surficial Mn crusts. The surficial Fe-Mn crusts and macro-oncoids are hydrogenetic crusts related to the chemo-organotrophic behaviour of the benthic microbial communities in the External Subbetic. Encrusting foraminifera (Thurammina, Placopsilina, Tolypammina and nubeculariids) and fungi fed on bacteria, while the bacteria and fungi took advantage of the nutrient-rich foraminiferal excretions. The cryptic Fe-Mn crusts are also hydrogenetic crusts developed in the walls of submarine cavities and fractures in the External Subbetic at the time of the hardground development. They are endostromatolites consisting almost exclusively of Frutexites in the case of thin neptunian dykes, or serpulid-Frutexites assemblages in a large neptunian sill. This assemblage reflects the colonization of unfavourable environment (aphotic with low oxygenation) as a response to the photophobic behaviour of chemosynthetic and cryptobiontic microorganisms. Finally, the hydrothermal Mn crusts registered in the Rif are characterised by the record of bacillus-shaped bacteria and different type of filaments. The precipitation of manganese minerals is interpreted as induced by the chemo-organotrophic behaviour of benthic microbial communities, since manganese oxides may form as a result of the direct metabolic activity of bacteria in hydrothermal environments. Very well-preserved fungal hyphae evidence the presence of fungi that probably fed on bacterial communities and their by-products.
\end{abstract}

Keywords: hardground, fossil microbes, ferruginous crusts, manganesiferous crusts, Subbetic, Rif.

\section{RESUMEN}

El límite Jurásico Medio-Superior en el Subbético Externo (Cordillera Bética) y el Grupo Jbel Moussa (Dorsal Calcárea Rifeña) se caracteriza por la presencia de numerosas rupturas sedimentarias representadas como paleokarsts, superficies de omisión y hardgrounds. Los rasgos y el número de discontinuidades es variable dependiendo del dominio estudiado y de la unidad tectónica considerada, pero un rasgo habitual es la presencia de depósitos laminados de óxidos y oxihidróxidos de hierro y manganeso de origen microbiano. Se ha identificado tres diferentes contextos para el desarrollo de este tipo de depósitos: a) costras y macro-oncoides de Fe-Mn superficiales, b) costras de Fe-Mn crípticas, y, c) costras manganesíferas hidrotermales. Las costras de Fe-Mn superficiales son depósitos hidrogenéticos relacionados con la actividad quimiorganotrófica de comunidades bentónicas microbianas sobre los hardgrounds del Subbético Externo. En estas costras abundan los foraminíferos encostrantes (Thurammina, Placopsilina, Tolypammina y nubeculáridos) y los hongos, que probablemente se alimentaron de las bacterias, mientras que tanto las bacterias como los hongos pudieron beneficiarse de las excreciones de los foraminíferos. Las costras se desarrollaron en cavidades y fracturas en el fondo marino paralelamente al desarrollo de los hardgrounds. Estas costras endoestromatolíticas están constituidas mayoritariamente por Frutex- 
ites, y localmente por la asociación serpúlido-Frutexites; representan la colonización de ambientes carentes de luz y mal oxigenados por parte de organismos criptobiontes quimiosintéticos con comportamiento fotófobo. Por último, las costras manganesíferas hidrotermales identificadas en el Rif se caracterizan por el registro de formas tipo bacilo y abundantes filamentos, estos últimos asignados a hifas de hongos. La precipitación de los minerales de Mn fue inducida por bacterias con comportamiento quimiorganotrófico relacionadas con surgencias hidrotermales enriquecidas en metales, de las cuales se alimentaron los hongos habitualmente descritos en este tipo de ambiente submarino.

Palabras clave: hardground, microbios fósiles, costra ferruginosa, costra manganesífera, Subbético, Rif.

\section{INTRODUCTION}

Iron and manganese crusts are grouped into three genetic types: hydrogenetic, diagenetic and hydrothermal classes (Bolton et al., 1988; Hein et al., 1997; Glasby,
2000; Rojkovič et al., 2003; Jach \& Dudek, 2005). Hydrogenetic deposits form directly from seawater in an oxidizing environment (Glasby, 2000). Diagenetic deposits result from oxic-diagenesis within the underlying sediments, leading to an upward supply of Fe and Mn from

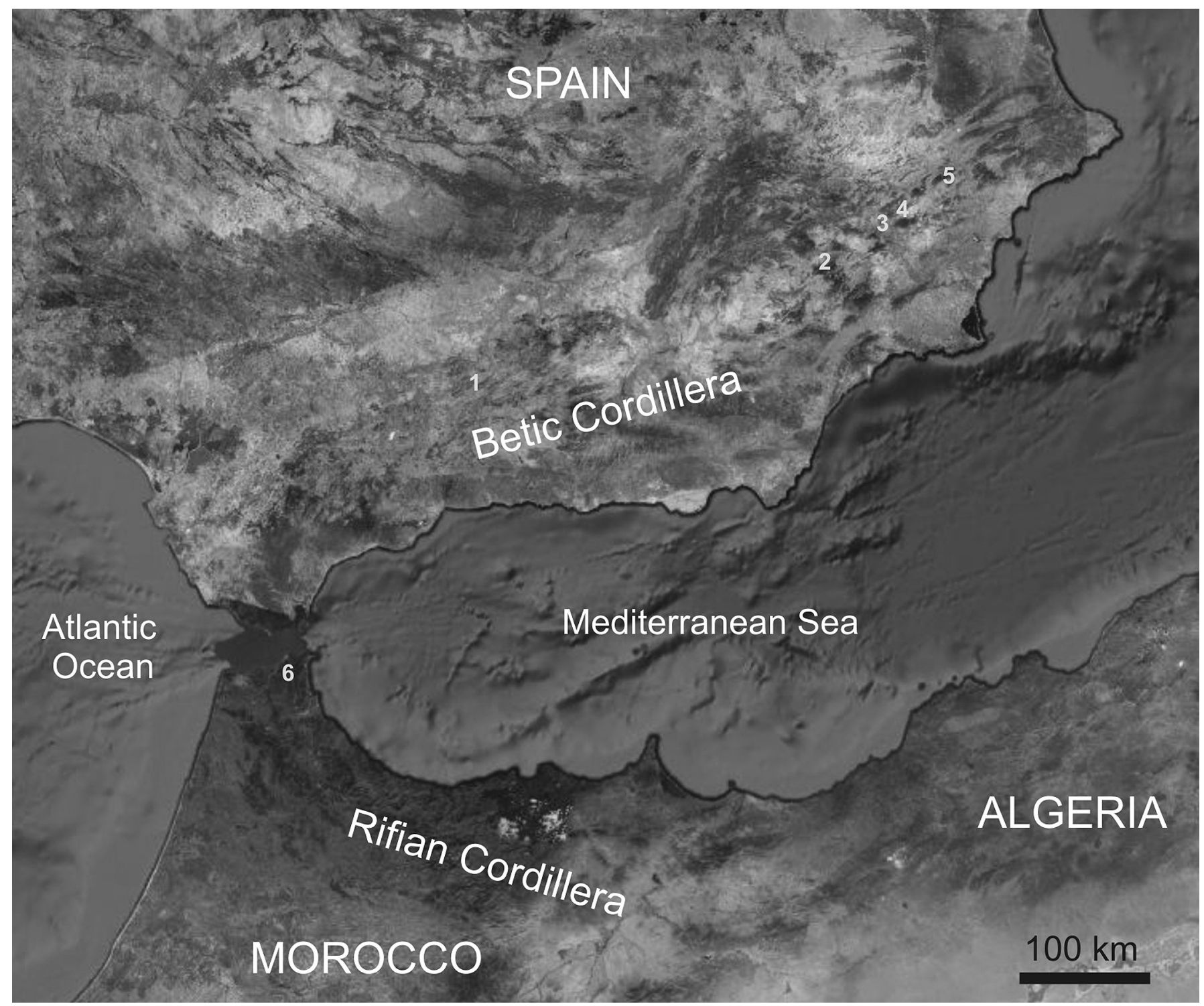

Figure 1. Location of studied outcrops in the Betic-Rifian Cordillera. 1. Central External Subbetic of Córdoba (Sierra de Cabra); 2-5. Eastern External Subbetic: 2. Sierra de Quípar, 3. Sierra de Lúgar, 4. Sierra de Corque and 5. Sierra de Reclot; 6. Rifian Cordillera, Jbel Moussa Group. 
the sediment column, and they are characterised by faster growth rates. Hydrothermal deposits precipitate directly from hydrothermal solutions that are vented in areas with high heat flow associated with submarine volcanism, such as mid-ocean ridges, back-arc basins and hot spot volcanoes (Glasby, 2000). The presence and the mediation of microbes in the formation of $\mathrm{Fe}$ and $\mathrm{Mn}$ crusts is fairly usual in the case of hydrothermal and hydrogenetic crusts. A detailed analysis of fossil benthic microbial communities from these types of deposits is not common, however (Martín-Algarra \& Sánchez-Navas, 2000; Reolid \& Nieto, 2010; Préat et al., 2011; Reolid et al., 2011; RodríguezMartínez et al., 2011). This research is focused on the study of benthic microbial communities from distinct types of Fe and Mn crusts of the Jurassic hardgrounds from the Western Tethys.

The Middle-Late Jurassic transition in the Western Tethys was characterised by discontinuous sedimentation with complex stratigraphic breaks. Such unconformities are represented in numerous domains presenting iron and manganese deposits: the Iberian Range (Aurell et al., 1994, 1999; Ramajo \& Aurell, 1997; Ramajo et al., 2002; Meléndez et al., 2005), the Côte D'Or (Courville \& Collin, 1997), Schaignay (Scouflaire et al., 1997), the southeastern Paris Basin (Lorin et al., 2004; Collin et al., 2005), the Swiss Juras (Gygi, 1981; Huber et al., 1987), Swabia (Gygi \& Persoz, 1987) and the Maghreb (Soussi \& M'rabet, 1991; El Kadiri, 2002). In the case of the deposits of the Betic Cordillera, which represented the SouthIberian Palaeomargin during the Mesozoic (Figs. 1 and 2), important stratigraphic gaps and unconformities have been registered during the Bathonian-Oxfordian (Sequeiros, 1974, 1987; Seyfried, 1978; García-Hernández et al., 1980, 1989; Sandoval, 1983; Marques et al., 1991; Martín-Algarra \& Vera, 1994; O’Dogherty et al., 2000; Vera, 2001; Reolid et al., 2008, 2010).

The aim of this work is the analysis of the benthic microbial communities related to the Fe-Mn crusts of the unconformities registered from the Early Bathonian to the Middle Oxfordian in the External Zones of the Betic Cordillera and in the Rifian Cordillera (Fig. 1), respectively representing the northern and southern palaeomargins of the Western Tethys.

\section{GEOLOGICAL SETTING}

The western Mediterranean Sea is bordered by three alpine systems: the Maghrebian Cordillera (Rif, Tell, and Sicily), the Betic Cordillera, and the Apennines. They are linked by the Gibraltar Arc and the Calabria-Peloritani Arc, two major tectonic features that illustrate the connection between different cordilleras and reveal the gradual change of vergence from one chain to another (Guerrera et al., 1993).
The outcrops studied correspond to different branches of the Betic-Rifian Cordillera, connected by the Gibraltar Arc (Fig. 1). In the Betic Cordillera, the analysed sections correspond to the Central and Eastern parts of the External Subbetic, whereas in the Rifian Cordillera the studied sec-
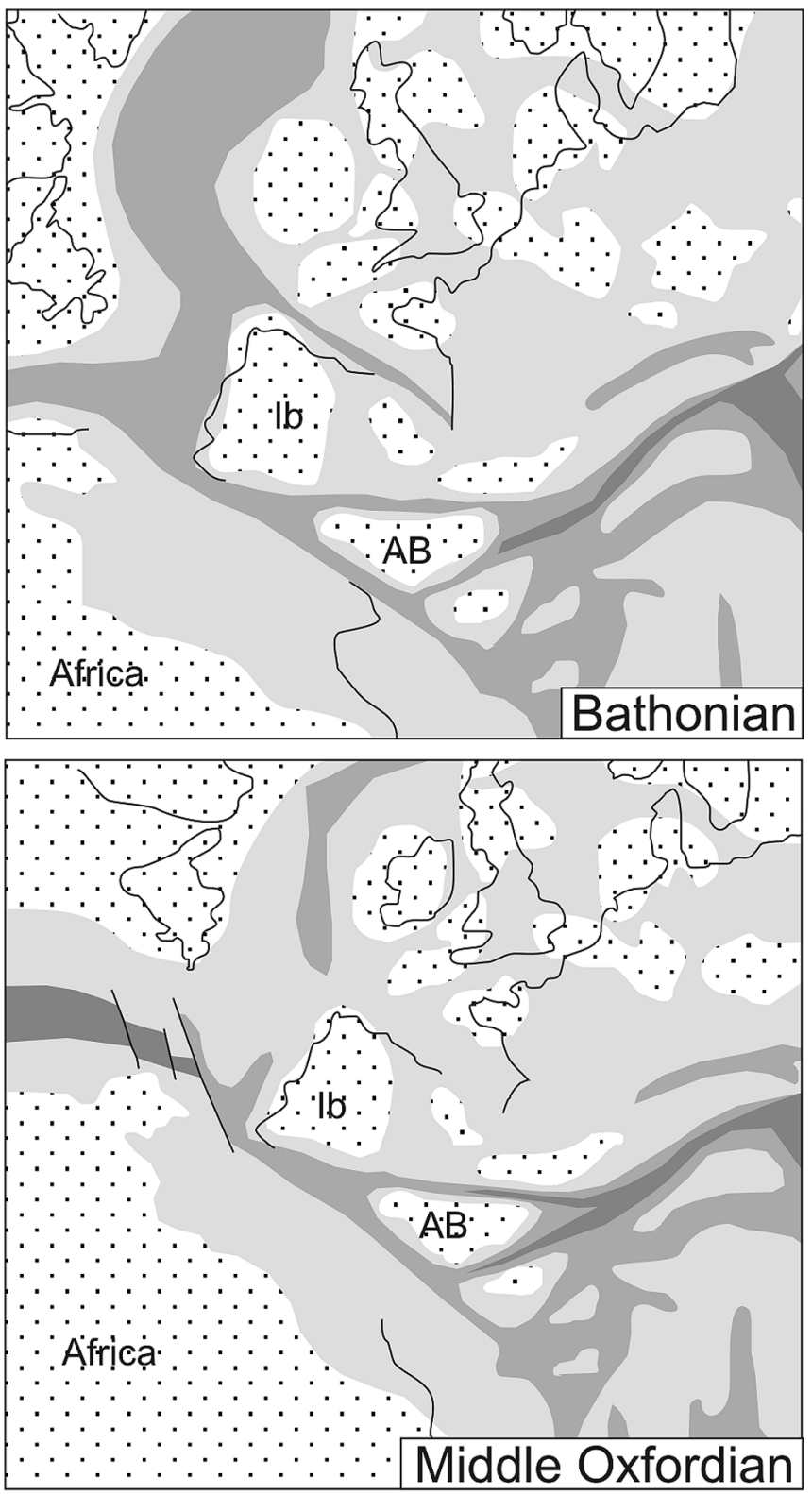

$\because \therefore$

Emerged continental areas

Epicontinental seas

Deep marine areas with thin continental crust

Deep marine areas with oceanic crust

Figure 2. Palaeogeographic reconstruction of the Westernmost Tethys during the Bathonian and the Middle Oxfordian (modified from Ziegler, 1988). Note: Ib, Iberian Massif; AB, Alboran Block. 
tion crops out in the northernmost part of the Rifian Calcareous Chain, corresponding to the Jbel Moussa Group (Durand-Delga \& Villiaumey, 1969).

\section{CENTRAL EXTERNAL SUBBETIC}

The External Subbetic is a domain of the Subbetic, located between the Intermediate Units to the North and the Middle Subbetic to the South (Vera, 2001).

In the Central External Subbetic, the top of the Camarena Formation (Camarena Lanchares Unit) contains a hardground with Fe-Mn crusts. The Camarena Fm. (Bajocian-Bathonian) is composed by oolitic limestones representing a shallow marine platform (Fig. 3). Overlying this unconformity is the Upper Ammonitico Rosso Fm. (Callovian-Berriasian), made up of condensed facies deposited in a pelagic swell. The age of the unconformity varies, with a maximum from Late Bathonian to Late Oxfordian (Molina, 1987). Neptunian dykes and sills are abundant at the top of Camarena Fm., interpreted as having a palaeokarstic origin (Molina et al. 1995, 1999). The studied outcrop is located in the Barranco de Navahermosa $\left(37^{\circ} 30^{\prime} 7^{\prime \prime} \mathrm{N}, 4^{\circ} 18^{\prime} 32^{\prime \prime} \mathrm{W}\right)$.

\section{EASTERN EXTERNAL SUBBETIC}

The outcrops selected in the Eastern External Subbetic are located in the provinces of Murcia and Alicante (SE Spain) and correspond to three tectonic units: Reclot, Lúgar-Corque and Quípar. These are characterised by shallow shelf deposits of the lowermost Jurassic (Gavilán Fm), overlain by pelagic and hemipelagic facies (Zegrí Fm, Veleta Fm and Upper Ammonitico Rosso Fm). After fragmentation of the Lower Jurassic carbonate platform, the External Subbetic was structured into pelagic swells controlled by listric faults (e.g., Vera, 2001; Vera et al., 2004). During the Middle Jurassic, sedimentation in these pelagic swells varied, between cherty limestones (Veleta Fm) and ammonitico rosso facies (Upper Ammonitico Rosso Fm), depending on the tectonic unit. The Upper Jurassic is represented only by the Upper Ammonitico Rosso Fm in all tectonic units.

A lower and an upper member can be differentiated in the Upper Ammonitico Rosso Fm (Fig. 3). These members are bound by complex hardgrounds representing the Bathonian and Callovian unconformities with Fe-Mn crusts and macro-oncoids. The lower member of the Upper Ammonitico Rosso Fm (Middle Jurassic) is made up of well compacted red nodular limestones, whereas the upper member of the Upper Ammonitico Rosso Fm (Upper Jurassic) is made up of marly nodular red limestones, red limestones, and nodular pink limestones (Fig. 3). Authors Rey (1993) and Nieto (1997) studied the stratigraphy of the formation in this area, showing that the top of the lower member and the base of the upper member of the Upper Ammonitico Rosso Fm are diachronous. The studied sections//outcrops are distributed in three tectonic units of the Eastern External Subbetic (within the provinces of Alicante and Murcia; Fig. 1): the Reclot Unit [Rambla Honda-1 (38 $20^{\prime} 52^{\prime \prime} \mathrm{N}, 0^{\circ} 55^{\prime} 40^{\prime \prime} \mathrm{W}$ ) and Rambla Honda-2 $\left.\left(38^{\circ} 20^{\prime} 51^{\prime \prime} \mathrm{N}, 0^{\circ} 55^{\prime} 22^{\prime \prime} \mathrm{W}\right)\right]$, the Lúgar-Corque Unit [Caprés $\left(38^{\circ} 14^{\prime} 13^{\prime \prime} \mathrm{N}, 1^{\circ} 07^{\prime} 50^{\prime \prime} \mathrm{W}\right)$, Lúgar 62-1 $\left(38^{\circ} 12^{\prime} 24^{\prime \prime} \mathrm{N}, 1^{\circ} 10^{\prime} 46^{\prime \prime} \mathrm{W}\right)$ and Lúgar 62-2 (38 $20^{\prime} 51^{\prime \prime} \mathrm{N}$, $\left.0^{\circ} 55^{\prime} 22^{\prime \prime} \mathrm{W}\right)$ ] and the Quípar Unit [Quípar $\left(38^{\circ} 03^{\prime} 10^{\prime \prime} \mathrm{N}\right.$, $\left.\left.1^{\circ} 48^{\prime} 15^{\prime \prime} \mathrm{W}\right)\right]$.

In the Bathonian-Oxfordian time interval of the Upper Ammonitico Rosso Fm. one may observe numerous stratigraphic breaks identified as hardgrounds: the LowerMiddle Bathonian hardground (atop the Zigzagiceras zigzag Biozone), the Middle-Upper Bathonian hardground (atop the Bullatimorphites costatus Biozone), and the Callovian-Oxfordian hardground. The hiatus associated with each hardground varies from one tectonic unit to the next, and sometimes even among outcrops within the same tectonic unit.

\section{RIFIAN CALCAREOUS CHAIN}

The studied Jurassic manganese crust is located precisely in the Gibraltar Arc and crops out in the northernmost end of the Rifian Calcareous Chain (Rifian Dorsale Calcaire), an area pertaining to the Jbel Moussa Group (Durand-Delga \& Villiaumey, 1969). This group, which overhangs the Gibraltar Strait, originated from a Jurassic pelagic swell involving the external zones of the Gibraltar Arc (i.e., the Tariquid Ridge of Durand-Delga, 1972). The Betic-Rifian or Alboran Block is the westernmost part of the Mesomediterranean Terrane (Guerrera et al., 1993; O'Dogherty et al., 2001). In turn, the Jbel Moussa Group constitutes the northern part of the Rifian Calcareous Chain and is composed by $4 \mathrm{~km}$-scale tectonic units represented by juxtaposed tilted blocks (Jbel Moussa, Jbel Juimâa, Ras Leona and Leila) of a Jurassic continental passive palaeomargin. Detailed stratigraphic analyses carried out by El Kadiri et al. (1990) and El Hatimi (1991) show that the Jbel Moussa Group is equivalent to the Spanish Penibetic and Subbetic domains, depending on the exact places. From a stratigraphic point of view, the Jbel Moussa Group contains, in a single succession, the typical facies of the Internal Calcareous Chain (white massive limestones of the Lowermost Jurassic, Fig. 3) and those of the External Calcareous Chain (red radiolarites of the Middle and Upper Jurassic, Fig. 3).

The studied manganese crust occurs in the western part of the Ras Leona High, close to an old mining site ("Col de la Mine" of French authors) located $1.5 \mathrm{~km}$ west of the village of Beliounis $\left(35^{\circ} 54^{\prime} 08^{\prime \prime} \mathrm{N}, 5^{\circ} 24^{\prime} 52^{\prime \prime} \mathrm{W}\right)$. The studied discontinuity surface corresponds to the HG.5 of El Kadiri (2002), who assigned it to the Upper Bajocian based on dating inferred from radiolarites of nearby Beliounis (El Kadiri, 1991). The studied manganese crust lies between Lower Jurassic massive limestones and the overlying Upper Jurassic radiolarites (Reolid et al., 2011). 


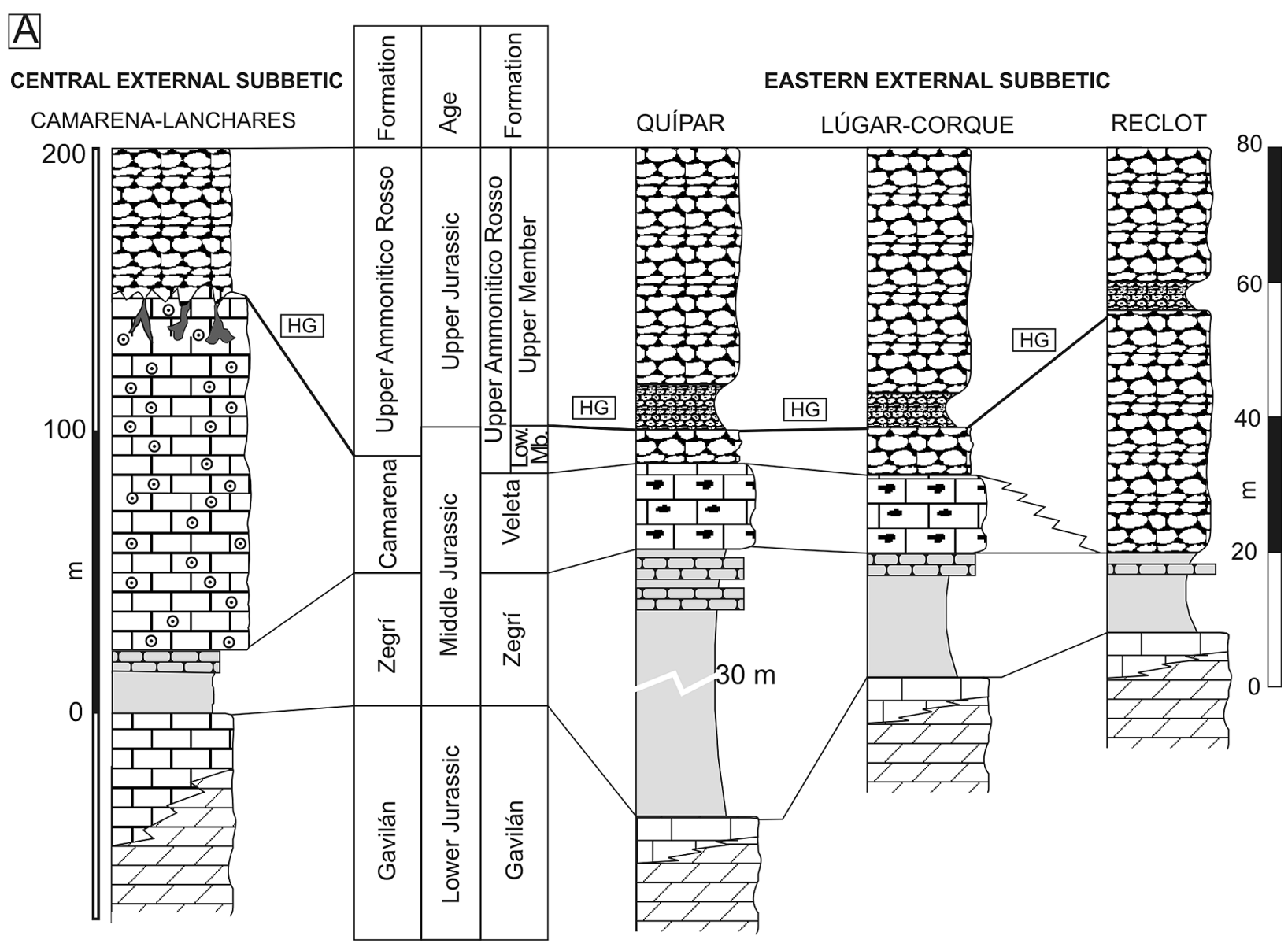

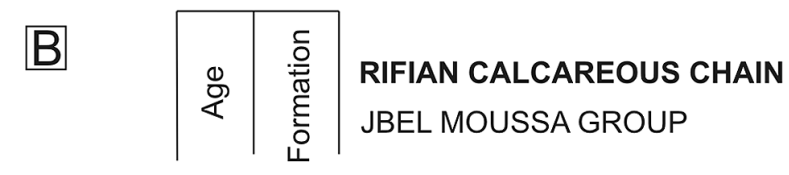

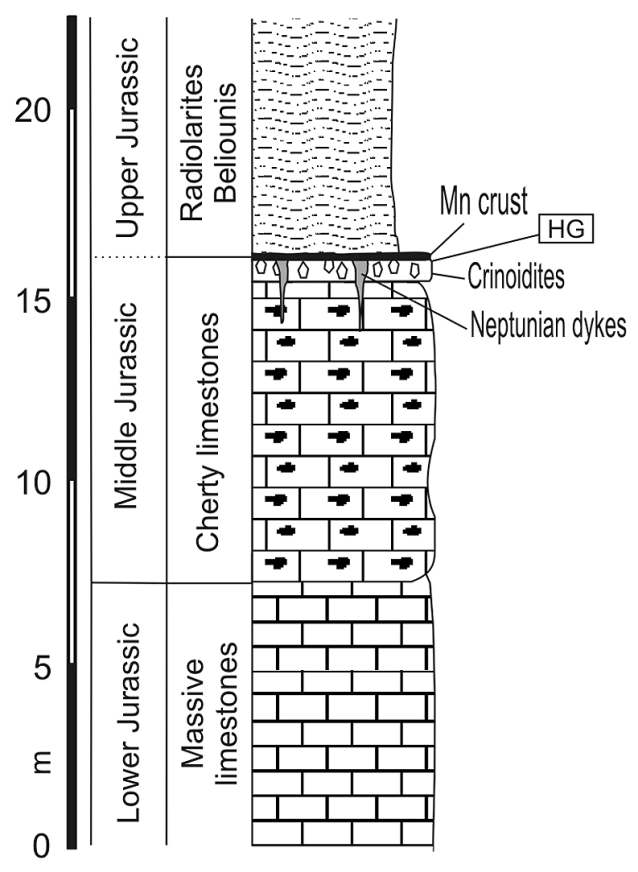

Radiolarites

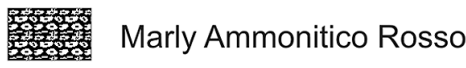

Calcareous Ammonitico Rosso

एंता Oolitic and oncolitic limestones

-1 Cherty limestones

Nodular limestones

$\square$ Marls and marly limestones

Shallow platform limestones

Z, Dolostones

HG Hardgrounds with Fe-Mn crusts

Figure 3. Synthetic stratigraphic sections of the Jurassic in the different tectonic units studied (modified from Reolid et al., 2010). 


\section{MATERIAL AND METHODS}

This research is based on the study of Fe-Mn crusts from 8 outcrops with hardground surfaces related to the Middle-Upper Jurassic boundary: 1 section from the Central External Subbetic, 6 sections from the Eastern External Subbetic and 1 from the Rifian Calcareous Chain.

A petrographic microscope was used to determine textures of host rocks and Fe-Mn crusts from 450 thin sections. Moreover, 20 polished sections were prepared for analysing geometric relationships between $\mathrm{Fe}-\mathrm{Mn}$ crusts and hosting rocks.

A total of $190 \mathrm{Fe}-\mathrm{Mn}$ macro-oncoids were characterised according to coating structure, diameter, nucleus size and coat thickness. Mineral composition of the crusts was examined by $\mathrm{X}$-ray diffraction (XRD), as described in previous work (for details see Reolid et al., 2010, 2011).

Carbon-coated polished thin-sections were examined under SEM using back-scattered electron (BSE) imaging and energydispersive X-ray (EDX) analysis in order to obtain textural and chemical data. These observations were carried out using a Zeiss DSM 950 SEM equipped with an X-Ray Link Analytical QX2000 EDX system, at the Centro de Instrumentación Científica (CIC, Universidad de Granada).

In addition, Fe-Mn encrustations were split; broken pieces from the inner surfaces of the crusts were mounted, coated with gold, and examined under the SEM using secondary electrons to study potential mineralogical and microbial structures. The equipment used was a SCI Quanta 400 located at the CIC (Universidad de Granada).

Whole-rock analyses of major elements of the crust were carried out using X-ray fluorescence (XRF) in a Philips PW 1040/10 spectrometer. Trace elements were additionally analysed using an inductively coupled plasma-mass spectrometer (ICP-MS) Perkin Elmer Sciex-Elan 5000 at the CIC (Universidad de Granada).

Thin sections were stained using the nuclear counterstain DAPI (4',6-diamidine-2-phenylindole), which is a fluorescent stain that binds strongly to DNA, to rule out the occurrence of recent microbes. Analysis of the staining techniques was carried out with a Nikon E-800 fluorescence microscope and a Hamamatsu CCD camera at the Department of Experimental Biology (Universidad de Jaén). A Nikon DAPI-FITC filter set was used for optimal detection of DAPI, and the AnalySIS 2.11.005 program was used to process the images. The negative results of the thin sections stained with DNA stains (DAPI and PI) allowed us to rule out the presence of recent microbes from the inner parts of the Fe-Mn crusts and macro-oncoids.

\section{RESULTS}

\section{CENTRAL EXTERNAL SUBBETIC}

\section{Texture, mineralogy and geochemistry}

The iron crusts of study are $<5 \mathrm{~cm}$ thick, having developed on the hardground at the top of the Camarena Fm and growing in the walls of neptunian dykes and sills (Fig. 3). This crust sometimes appears as patches, while in other cases as a thin coat around small fragments of fossils (Fig. 4).

The top of the Camarena Fm is an irregular surface that suggests typical karstic morphologies such as kamenitzas (see Fig. 4C), though its subaerial or submarine origin is a matter of debate (Molina et al., 1995, 1999). The infilling of these cavities, which constitute the neptunian dykes and sills, is a pink limestone with microfacies similar to
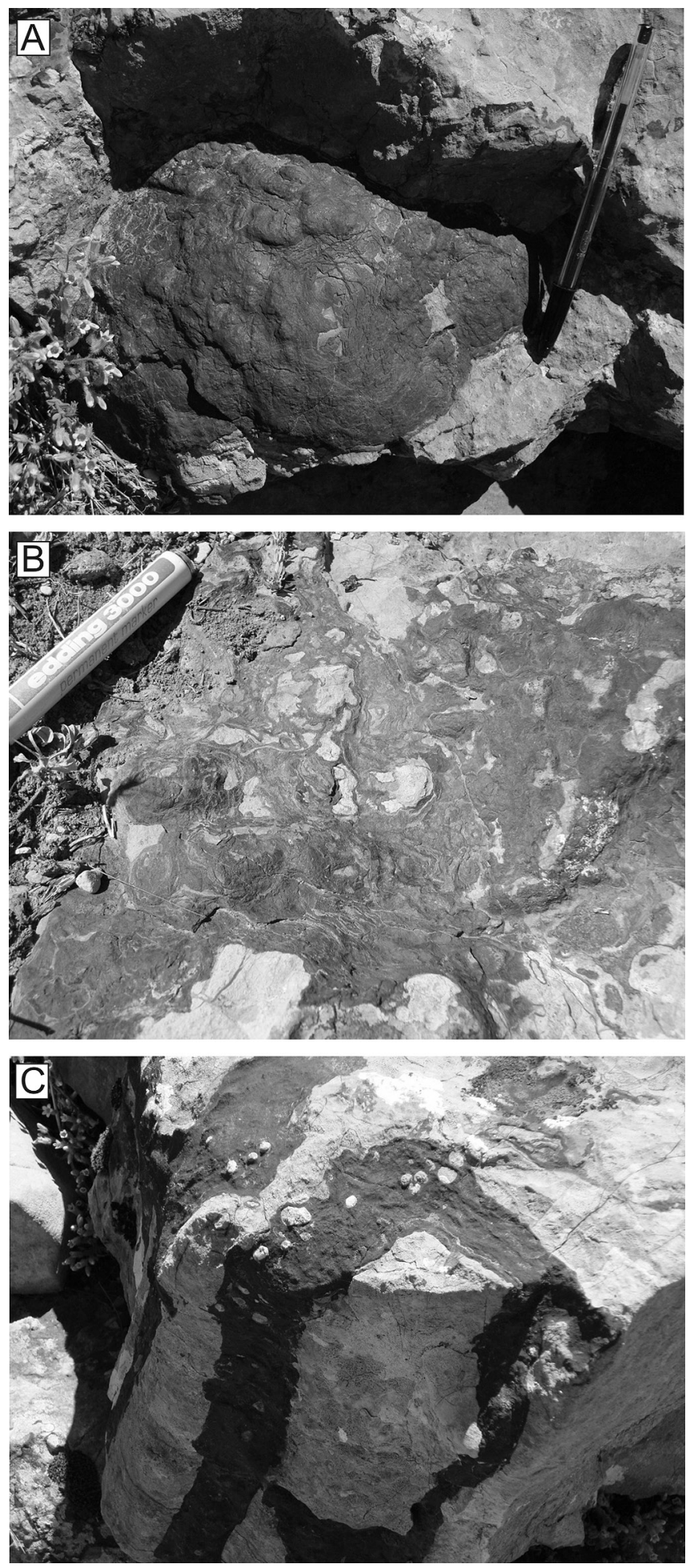

Figure 4. Ferruginous crusts in the Navahermosa outcrop. A. and B. Surficial crusts on the hardground. C. Ferruginous endostromatolite growth in a palaeokarstic (kamenitza-like) structure. 
the ammonitico rosso facies (Molina, 1987; Molina et al., 1999). Some iron crusts are developed within the walls of these cavities; indeed, the smaller cavities are infilled exclusively by laminated iron crusts (Fig. 4C). Such cavity and fissure dwelling stromatolites were denominated endostromatolites by Monty (1984). These are cryptic crusts because they are developed in protected shadow places of the sea-bottom.

Notwithstanding, the most interesting cryptic crusts are related to a large neptunian sill $(3 \mathrm{~m}$ high and $13 \mathrm{~m}$ long). This neptunian sill has a pelagic infilling of ammonitico rosso facies from the Callovian to the Upper Tithonian constituted by wackestones of Globuligerina and Bositra buchi. The crust, over $3 \mathrm{~cm}$ thick, is developed at the top of the cavity and contains a dense aggregate of serpulids growing downward and coated by iron crusts with an arborescent to dendrolitic microstructure (Reolid \& Molina, 2010).

The crusts studied in the Central External Subbetic are constituted mainly by goethite and calcite, with a $\mathrm{Fe}_{2} \mathrm{O}_{3}$ content between 4 and $20 \mathrm{wt} . \%$, less than $7 \mathrm{wt} . \%$ of $\mathrm{MnO}$, and a clearly positive anomaly of $\mathrm{Ce}\left(\mathrm{Ce} / \mathrm{Ce}^{*}=3.54\right)$. The analysis of thin sections revealed planar and arborescent morphologies (Figs. 5A and B). The planar morphologies are characterised by an alternance of clear and dark laminae corresponding to microbial lamination similar to that described by Reolid \& Nieto (2010). The laminae thickness ranges between 20 and $140 \mu \mathrm{m}$. In the arborescent morphologies, lamination is less evident due to the darker colour than in the planar morphologies as a result of the higher $\mathrm{MnO}$ content.

\section{Microbiota}

The Fe-Mn crusts show a dense accumulation of fibrillar meshworks with microbial appearance as well as abundant encrusting foraminifera (Vinelloidea and Placopsilina). Other typical structures are segmented filaments $(20-30 \mu \mathrm{m})$. Sometimes they resemble boring in the planar lamination. These are most likely fungi.

SEM images allowed us to identify dense webs of straight and slightly curved filaments with a cylindrical shape measuring 2 to $10 \mu \mathrm{m}$ in diameter (Fig. 6). These filaments show branching at various angles and without any evident pattern. Similar filaments have been interpreted by Reolid \& Nieto (2010) as fungal hyphae.

In the arborescent morphologies, the foraminifera are also abundant, while the genera are different than in the planar morphologies: Bullopora, Tolypammina and Thurammina (Fig. 5).

In the case of the crusts developed in the walls of the large neptunian sill, the boundstone is composed of serpulid bundles growing downward with thin iron crusts constituted by arborescent to dendrolitic microstructures (Fig. 5). The serpulids are the dominant fossil macroinvertebrates and were the primary bioconstructors, whereas all other organisms - foraminifera, gastropods and ostracodes - benefited from the free spaces among the serpulid tubes (Figs. 5C-F). The serpulid tubes are irregular and slightly sinuous, with a diameter of $0.29-3.22 \mathrm{~mm}$ and an average size of $1.05 \mathrm{~mm}$. Serpulids with a diameter $<1 \mathrm{~mm}$ are dominant, whereas mature tubes are comparatively scarce (see Reolid \& Molina, 2010, and Schlögl et al., 2008 for equivalent example from Western Carpathians). The walls of the tubes show microborings progressing from the outer side of the walls. The microborings are located in the downward parts of the tubes and mainly in specimens larger than $1.5 \mathrm{~mm}$ in diameter. The growth of these serpulid aggregates was accompanied by extensive Fe-Mn mineralization. The thin Fe crusts are widely extended on the outer side of the tubes with arborescent to dendrolitic microstructures (maximum $0.71 \mathrm{~mm}$ long and $0.32 \mathrm{~mm}$ wide, Figs. 5B-F). Detailed examination of dendrolitic iron structures with SEM reveals an alternation of thin concave laminae, 2.5 to $0.6 \mu \mathrm{m}$, of calcite and goethite (Fig. 6D). These microstructures were assigned to Frutexites shrubs by Reolid \& Molina (2010). There are many sessile foraminifera within the serpulid-Frutexites assemblage, attached to both the serpulid tubes and Frutexites columns (Figs. 5C-F). The most abundant foraminifera are Bullopora tuberculata (Polymorphinidae) and, secondarily, the agglutinated foraminifera Thurammina hausleri (Saccaminidae) and Tolypammina (Ammodiscidae). Usually there are no sessile foraminifera encrusted by Frutexites.

\section{EASTERN EXTERNAL SUBBETIC}

Texture, mineralogy and geochemistry

The Lower-Middle Bathonian hardground, the MiddleUpper Bathonian hardground, and the Callovian-Oxfordian hardground present abundant ferruginous crusts and macrooncoids composed by Fe-Mn oxyhydroxides (Jiménez-Millán \& Nieto, 2008). The Fe-Mn crusts and macro-oncoids extend over the hardground surface (Fig. 7). In general, they are characterised by brown and reddish colours. The Fe-Mn crusts have a 4-5 mm mean thickness and develop directly over the hardground. The ferruginous macrooncoids are made up by a core (mollusc fragment or undetermined lithoclast) coated by concentric laminae (Figs. 7B, C, and 8). Ammonoid shells and moulds are typical cores of the macro-oncoids studied (Reolid et al., 2010).

The mean size of the ferruginous macro-oncoids is 43 $\mathrm{mm}$, with variability from $10-108 \mathrm{~mm}$, and the thickness of the ferruginous coating is less than $30 \mathrm{~mm}$. However, in some macro-oncoids this coating is much thicker. The outer shape is irregular in outline, and subrounded, spheroidal to elongate.

The crusts have a poorly developed laminated structure, while the macro-oncoids have a very well developed laminated structure (Fig. 8). The laminated bands are almost concentric and symmetrically related to the nucleus (Fig. 7B). The bands consist of partially overlapping 

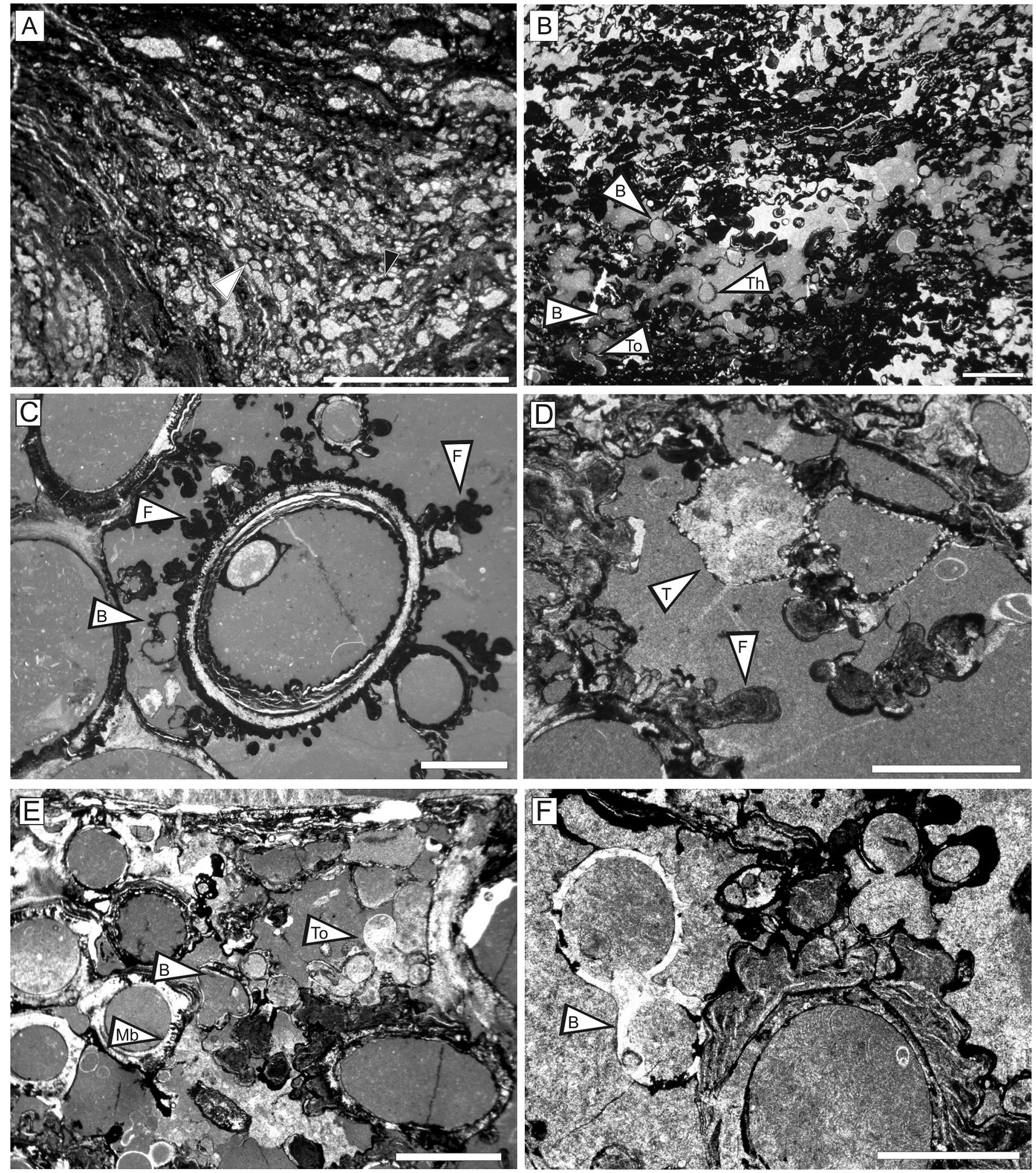

Figure 5. Aspects of the Fe-Mn crust under petrographic miscroscopy. A. Planar microbial laminated fabric with participation of encrusting foraminifera such as Placopsilina (arrow). B. Arborescent (dendrolitic) microbial fabric with abundant micritic sediment and participation of encrusting foraminifera as Tolypammina (To), Bullopora (B) and Thurammina (Th). C. Serpulid with encrustation by Frutexites (=F). The Fe-Mn crust was colonised subsequently by Bullopora tuberculata (=B). D. Sessile foraminifera Thurammina hausleri $(=\mathrm{T})$ with an agglutinated test constituted by quartz grains. E. Bullopora (=B) and Tolypammina (=To) colonising Frutexites. Microborings (Mb) are observed in a serpulid tube. F. Bullopora tuberculata $(=\mathrm{B})$ fixed to Frutexites. Scale bar $=1 \mathrm{~mm}$. 
laminae, usually alternating between light and dark (Figs. 8A, B). The banded coatings consist of laminae with planar and arborescent or club-shaped morphologies (Figs. 8 and 9). Arborescent morphologies develop from an initial planar lamination (Fig. 8B); among them, some small spokes are filled by pelagic sediment, mainly valves of filaments. Some arborescent morphologies evolve to dendrolitic ones with a dominant growth axis normal to the lamination (finger-like columns).

The ferruginous encrustations are constituted by laminated fabric with an alternance of clear and dark laminae (20-140 $\mu \mathrm{m}$ thick) with planar and arborescent morphologies (Fig. 8). Reolid \& Nieto (2010) have recognised a well-developed hierarchy of laminae in different scales of superimposed rhythms in the growth of the macro- oncoids. Depending on the morphology of the laminae, the rhythms can be classified as planar lamina-bearing rhythms and as arborescent lamina-bearing rhythms (Fig. 8 ). The mean thickness of the arborescent lamina-bearing rhythms is $2.43 \mathrm{~mm}$, greater than that of planar laminabearing rhythms $(0.92 \mathrm{~mm})$. Similarities have been found between these rhythms and those described by Han et al. (2003) in Pacific ferromanganese nodules, and by MartínAlgarra and Vera (1994) in phosphate stromatolites from the Penibetic (Betic Cordillera, Spain).

The hardground surface associated with the Bathonian hardgrounds presents neptunian dykes (Reolid et al., 2010). They were cavities with planar walls separated at a distance of 0.5 to $37 \mathrm{~cm}$. When the thickness of the neptunian dyke is $>4 \mathrm{~cm}$, endostromatolites are seen (sensu Monty,
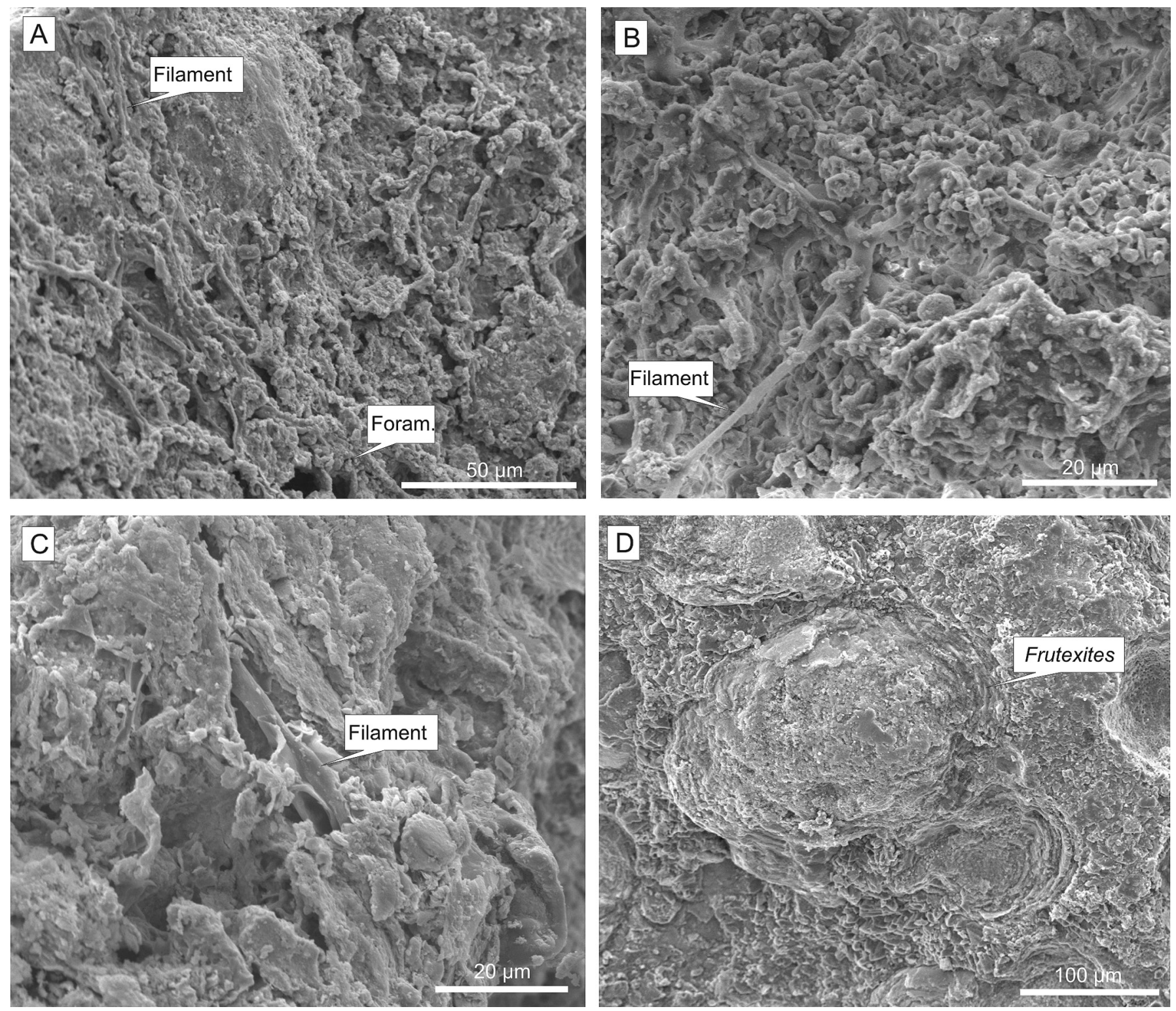

Figure 6. Microbial filaments (A, B, and C) and Frutexites (D) observed in the Fe-Mn crust of the Central External Subbetic under secondary electron images of SEM. 
1984; Burkhalter, 1995) with arborescent morphologies growing from the cavity walls (Fig. 7D).

The mineral association both in ferruginous macrooncoids and crusts is made up of goethite, calcite, lithiophorite and cryptomelana (Jiménez-Espinosa et al., 1997; Jiménez-Millán \& Nieto, 2008). In general, the $\mathrm{Fe}_{2} \mathrm{O}_{3}$ proportion in crust and macro-oncoids is around $34.5 \%$. The $\mathrm{Mn}$ content is always lower than $20 \%$ (mean value $=9.6 \%$ ) and the $\mathrm{Fe} / \mathrm{Mn}$ ratio is usually less than 30 . The crusts are enriched in $\mathrm{Co}, \mathrm{Ni}, \mathrm{As}$ and $\mathrm{Sb}$, while the REE content is close to the hydrogenetic recent Fe-Mn crusts (Fleet, 1983; Fromm et al., 2005). These crusts present a positive anomaly in Ce (Jiménez-Millán \& Nieto, 2008).

\section{Microbiota}

Under petrographic microscopy, the lamination can be attributed to the activity of benthic microbial communities.
Planar and arborescent laminated textures have been traditionally interpreted as microbialites, mainly in the case of carbonates (Burne \& Moore, 1987; Reolid et al., 2005; Nose et al., 2006; Perri \& Tucker, 2007; among others). Detailed analysis of the planar laminae reveals frequent microspheres with spherical to ovoid shapes and an average diameter of $40 \mu \mathrm{m}$ (Figs. 10A-C). They probably correspond to microbes. Filamentous microstructures parallel to lamination are observed in relation to these microspheres, with an average width of $8 \mu \mathrm{m}$ (Fig. 10A). In some cases the filamentous microstructures, which constitute fibrillar meshworks, contain small spheres forming a trichomal arrangement (Fig. 10B). The morphology and size of the microspheres and the filamentous microstructures resembles the filamentous cyanobacterium Microcoleus (Gerdes et al., 2000).

The arborescent to dendrolitic microstructures registered in the Fe-Mn crusts, macro-oncoids and endostro-
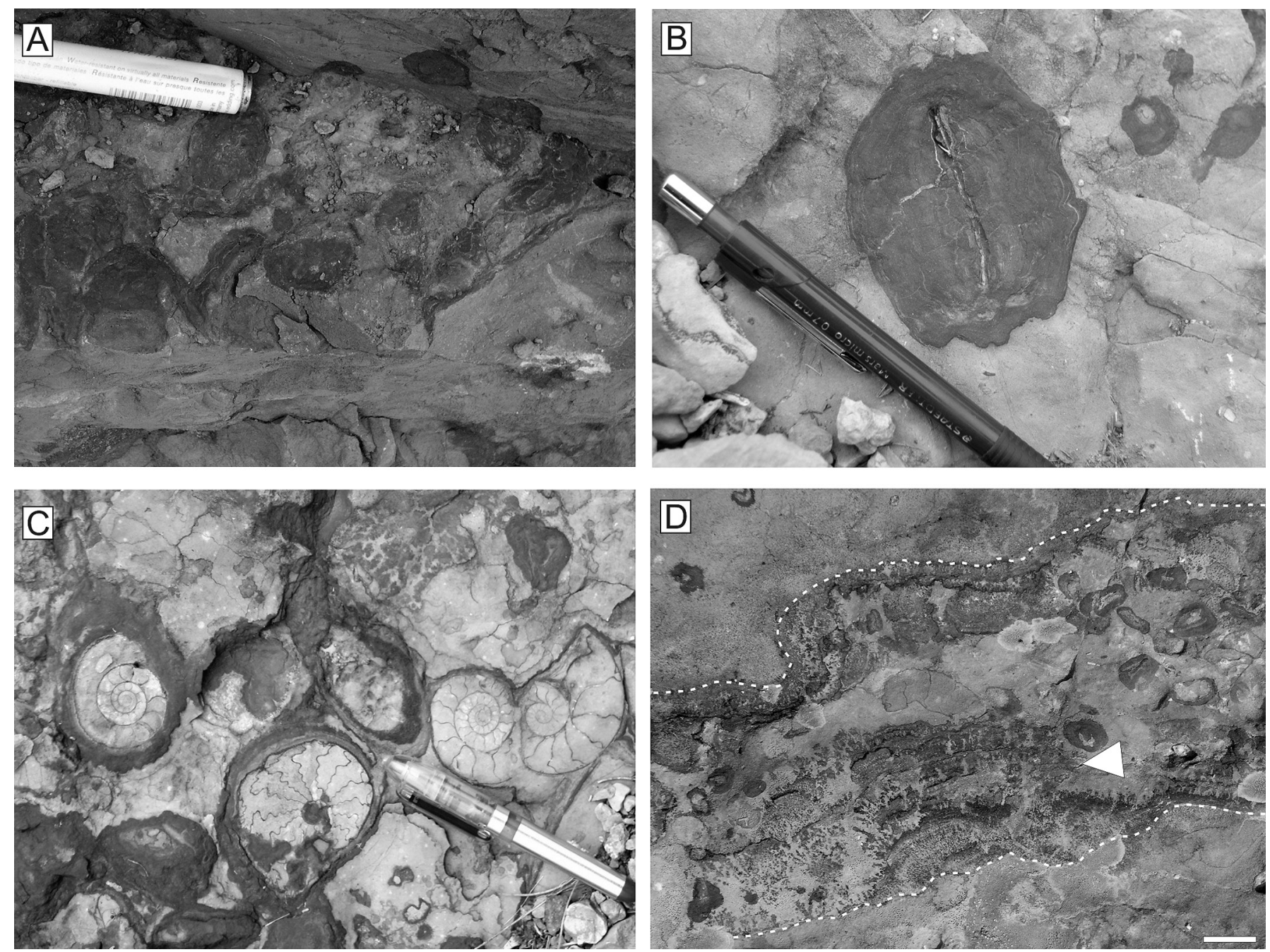

Figure 7. Filed view of the Fe-Mn crusts and macro-oncoids of the Eastern External Subbetic. A. Lower-Middle Bathonian hardground with banded Fe-Mn crusts and macro-oncoids (Rambla Honda-1 section, Reclot Unit). B. Fe-Mn macro-oncoid of the Callovian-Oxfordian hardground from the Sierra de Quípar (Quípar Unit). C. Ammonoids from the Callovian-Oxfordian hardground with microbial iron crust (Quípar Unit). D. Detail of a neptunian dyke with Fe-Mn endostromatolites in the walls (arrow) from the Lower-Middle Bathonian hardground of Rambla Honda-1 (Reclot Unit) Scale bar $=1 \mathrm{~cm}$. 
matolites are assigned to Frutexites shrubs (Figs. 8B, and 9C, D). It is not clear what type of microbe is involved in Frutexites. It has frequently been assigned a cyanobacterial origin (Playford et al., 1976, 1984; Nicoll \& Playford, 1993) with different types of cyanobacteria (Scytonematacean - Walter \& Awramik, 1979; Rivulariacean
- Hofmann \& Grotzinger, 1985; Angulocellularia group - Riding, 1991), and attributed to chemosynthetic bacteria (Cavalazzi et al., 2007).

Filamentous cyanobacteria and Frutexites can not be identified under SEM analyses. In this sense Dahanayake $\&$ Krumbein (1986) indicate that the filaments may be-
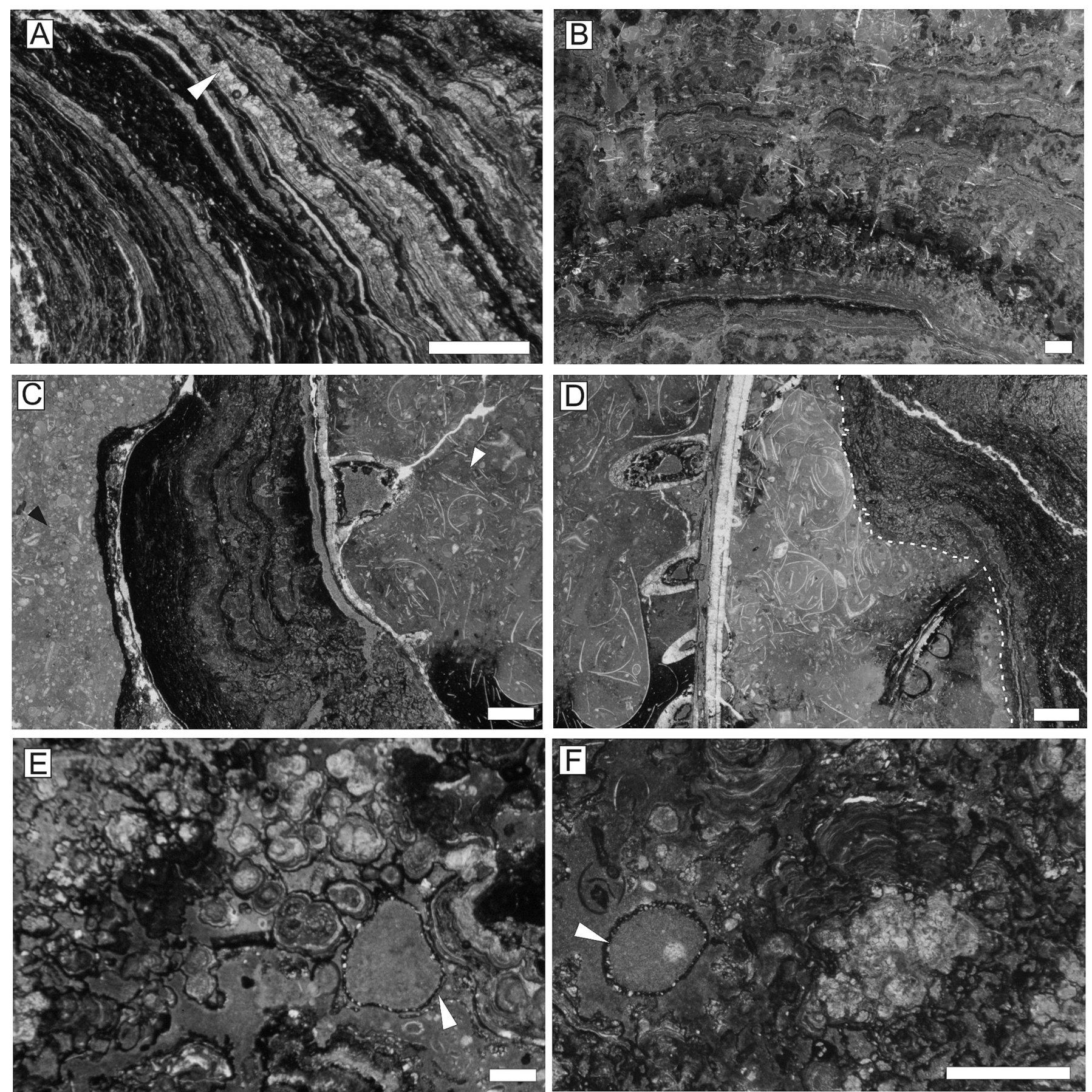

Figure 8. Examples of Fe-Mn crusts and macro-oncoids from Lúgar 62-1 (Lúgar-Corque Unit) in thin section. A. Detail of lamina pairs grouped in and dark thin intervals with calcitic laminae (arrow). B. Laminated textures with alternance of planar and arborescent morphologies revealing cyclicity. C. Fe-Mn macro-oncoid with an ammonoid as core; note the compossition of the mould (packstone of Bositra, white arrow) is different to the surrounding sediment (packstone of Globuligerina, black arrow). D. Ammonoid mould with a fragmented surface (dotted-line) encrusted by ferruginous microbialite. E. and F. Lamination club-shaped and Thurammina (arrow). Scale-bar $=1 \mathrm{~mm}$. 
come undetectable due to iron encrustation given the intense iron mineralization.

Filamentous and segmented structures $(20-30 \mu \mathrm{m}$ in diameter) have been observed in some parts of the Fe-Mn crusts and macro-oncoids. Sometimes they resemble boring in the planar lamination (Fig. 10D), and they are similar to those described from the Nava Hermosa section of the Central External Subbetic.

Some agglutinated foraminifera are registered in the Fe-Mn crusts and macro-oncoids, including Thurammina, Placopsilina and Tolypammina (Figs. 8E, F). Other organisms are recorded within the macro-oncoids, such as Bositra buchi and planktic foraminifera.

Some broken pieces from the inner laminae of these Fe-Mn macro-oncoids were analysed by SEM and allow us to characterise two types of microbial structures made up of calcite with Fe-Mn oxyhydroxide coatings or exclusively of Fe-Mn oxyhydroxides (Fig. 11):

a.- The most abundant microbial structure appears as straight to slightly curved cylindrical filaments ranging
2-3.5 $\mu \mathrm{m}$ in diameter and having a length over $0.7 \mathrm{~mm}$ (Figs. 11A, B). Occasionally these filaments are seen to branch without an apparent pattern. They filaments may be assigned to multicellular hyphae forming a fungal mycelium preserved by Fe-Mn oxyhydroxides.

b.- Other less common components are aggregates of bacillus-shaped forms with a maximum size of $\sim 2 \mu \mathrm{m}$ (Figs. 11C, D). These forms are very probably related to cyanobacteria, yet other possible types of eubacteria related to $\mathrm{Fe}$ and $\mathrm{Mn}$ oxidation cannot be ruled out.

\section{RIFIAN CALCAREOUS CHAIN}

Texture, mineralogy and geochemistry

In this sector, the discontinuity surface is directly overlain by a black crust $1-10 \mathrm{~cm}$ thick with submetallic luster (Fig 12A). The black crust overlies karstic neptunian dykes and sills formed by the infilling of open cracks or fissures by marine sedimentary material (El Kadiri, 2002). Under the petrographic microscope, the crust has a poorly developed laminated structure (Figs. 12B-D). Micro-
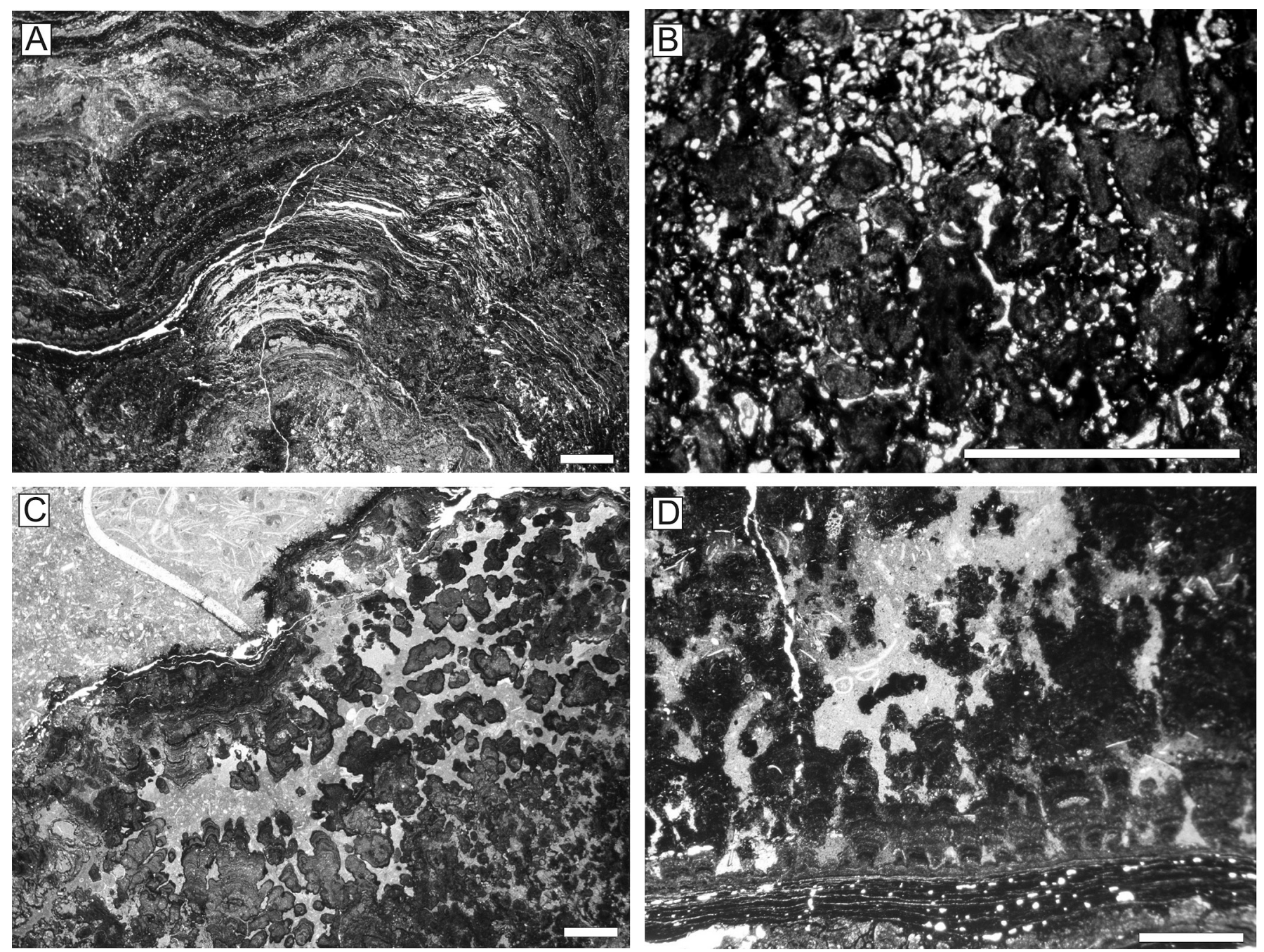

Figure 9. Fe-Mn macro-oncoids from the Quípar section (Quípar Unit). A. Planar laminated fabric (Sierra de Quípar). B. Segmented filamentous structures. C. and D. Arborescent laminated fabric (Sierra de Quípar). Scale-bar $=1 \mathrm{~mm}$. 
fissures and porosity in the underlain rocks (cherty limestones and crinoidal grainstones) favoured the downward progression of crustal mineralization (Figs. 12B, C). Examination of this black crust under the SEM reveals irregular lamination, 3-20 $\mu \mathrm{m}$ thick. Two types of planar lamination were differentiated by Reolid et al. (2011) according to the morphology:

- Crystalline planar lamination composed by laminae 10-20 $\mu \mathrm{m}$ thick, consisting of both small acicular and sheet crystals.

- Microbial planar lamination constituted by laminae of 3-8 $\mu \mathrm{m}$ mean-thickness and constituted by a dense web of filaments (Fig. 13).

Both types of laminations are irregularly distributed in the crust and no pattern of interlayering is observed.

The bulk chemical composition of the crust is characterised by a high content of $\mathrm{MnO}(72.0 \mathrm{wt} \%$ ). Other major components are $\mathrm{SiO}_{2}(2.3 \%), \mathrm{CaO}(1.7 \%), \mathrm{K}_{2} \mathrm{O}(1.1 \%)$ and $\mathrm{MgO}(1.1 \%) . \mathrm{Fe}_{2} \mathrm{O}_{3}$ and $\mathrm{Al}_{2} \mathrm{O}_{3}$ are $<1 \%$. In addition, the crust presents significant enrichments in $\mathrm{Sr}(1140 \mathrm{ppm}), \mathrm{Ba}$
(2125 ppm), Co (87 ppm), Ni (131 ppm), and $\mathrm{Cu}$ (201 ppm) with respect to the bulk composition of the upper continental crust (Post-Archaean Australian Shales, PAAS; Taylor \& McLennan, 1985). The sum of rare earth elements (REE) in the manganese crust $(10.9 \mathrm{ppm})$ is very low with respect to the PAAS (183.0 ppm), the light REE being more abundant than heavy REE. The chondrite-normalized REE patterns, using the CI carbonaceous chondrite (McDonough \& Sun, 1995), show two anomalies: one negative in $\mathrm{Ce}\left(\mathrm{Ce} / \mathrm{Ce}^{*}=\right.$ $0.56)$ and one positive in $\mathrm{Eu}\left(\mathrm{Eu} / \mathrm{Eu}^{*}=4.60\right)$. For more details on chemical composition, see Reolid et al. (2011).

$\mathrm{X}$-ray diffractograms and EDX analyses reveal that the crust is basically constituted by manganese oxides: $\mathrm{Ca}$ birnessite, cryptomelane and coronadite.

\section{Microbiota}

Microbial structures are mainly related to Ca-birnessite rich samples. The SEM analyses of the microbial laminae of the Mn crust revealed six types of microbial structures mineralized by Mn oxides:
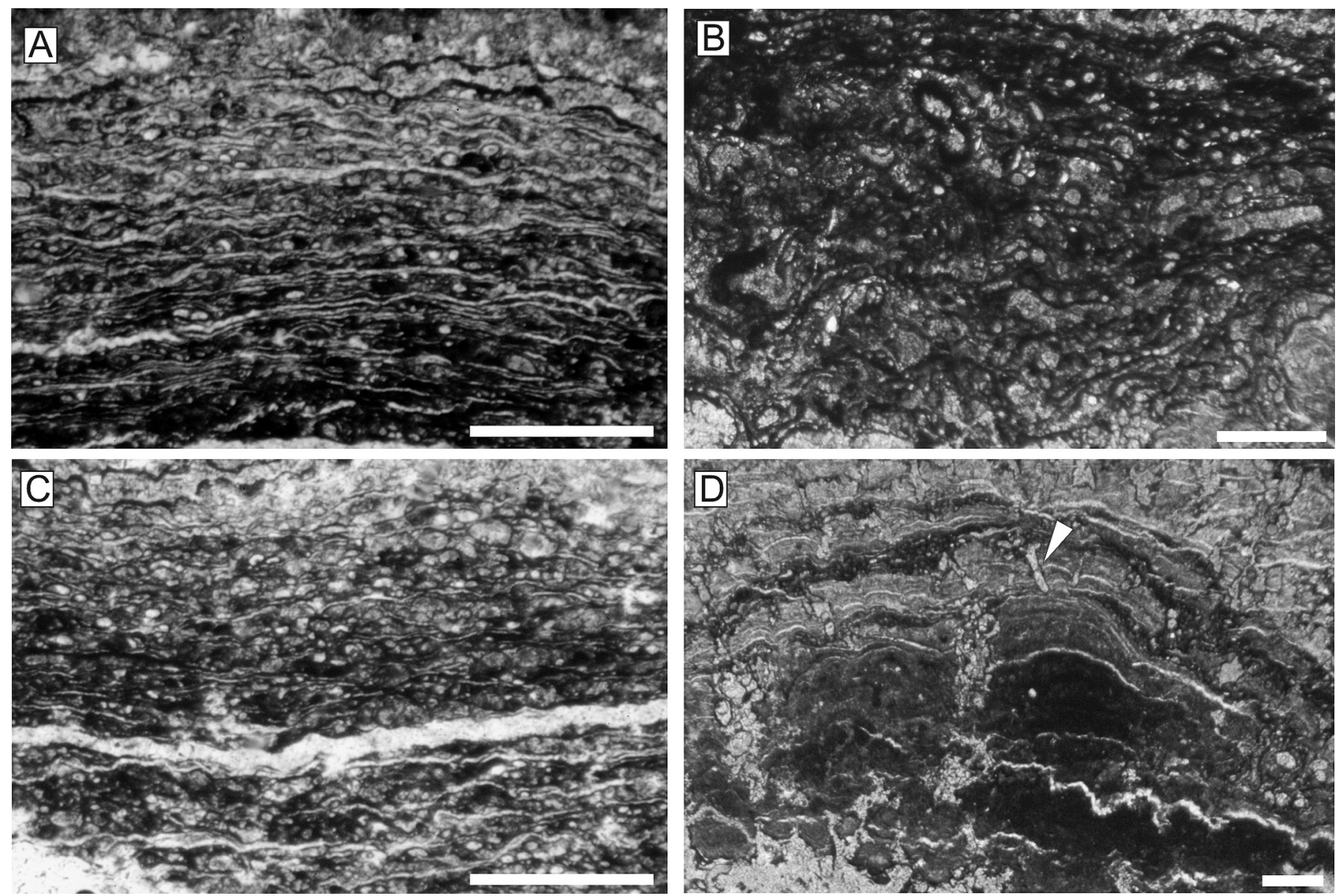

Figure 10. Microbes under thin section from Fe-Mn macro-oncoids of Lúgar 62-1 (Lúgar-Corque Unit). A. Detail of the planar laminated texture with fibrillar meshwork resembling a possible Microcoleus mat, arranged with their long axes parallel to the surface of the macro-oncoid core. B) Filamentous microstructures constituted by microspheres forming trichomal arrangements. C. Planar laminated fabric with fibrillar meshwork. D. Segmented filaments with appearance of microborings (arrow) in ferruginous macro-oncoids. Scale-bar $=0.5 \mathrm{~mm}$. 
a.- Webs of filaments with dense dichotomous branching: They are the most abundant microbial structures (Figs. 13 and 14A, B), appearing as a dense meshwork with thin, straight to slightly curved cylindrical filaments, ranging 2-4 $\mu \mathrm{m}$ in diameter and over $60 \mu \mathrm{m}$ in length. Dichotomous branching is common, mostly through $90-120^{\circ}$ angles. In some very well preserved cases, the filaments are partitioned by cellular cross-walls (septate). Some of these filaments present fragmentation following the septa. In other cases, a detailed analysis of the filament meshwork reveals particular filaments made by ovoid-like microspheres (6-7.5 $\mu \mathrm{m}$ length) forming a trichomal arrangement. Crowded mineralized filaments sometimes produce a continuous biofilm. A fungal origin is not ruled out; hence filaments could be multicellular hyphae forming a fungal mycelium preserved by Mn oxides. Some filaments probably correspond to septate fungi ascomycetes.

b.- Rugose simple filaments: They are filaments with uncommon branching (at $65^{\circ}$ angle), $<2 \mu \mathrm{m}$ in diameter and larger than $60 \mu \mathrm{m}$. Some of these filaments appear as aggre- gates of grains and they are unfilled tubes when the diagenesis is not intense (Fig. 14C). They present cellular cross-walls.

c.- Smooth simple filaments: They are filaments with scarce branching (at $65^{\circ}$ angle), $2 \mu \mathrm{m}$ in diameter and larger than $60 \mu \mathrm{m}$. The name "simple filament" is due to the scarcity of branching (Fig. 14D). The surface of the filament is smooth.

d.- Aggregates of bacillus-shaped forms: These are accumulations of ovoidal bodies with a size of 1.5-3.0 $\mu \mathrm{m}$ (Fig. 15). These forms are less common and probably related to bacteria.

e.- Bunches of segmented and branched filaments: These are thick filaments $(25-50 \mu \mathrm{m})$ larger than 700 $\mu \mathrm{m}$, with dichothomous branching in parallel filaments (Fig. 16A). The branches are segmented each 25-60 $\mu \mathrm{m}$ by septa. Both the external walls and the septum are thin. These structures are mineralised in Ca-birnessite and also present a thin coat $(2-5 \mu \mathrm{m})$ of this mineral surrounding the filaments, which are densely packed. These structures pertain to fungi (Alexopoulos et al., 1996).
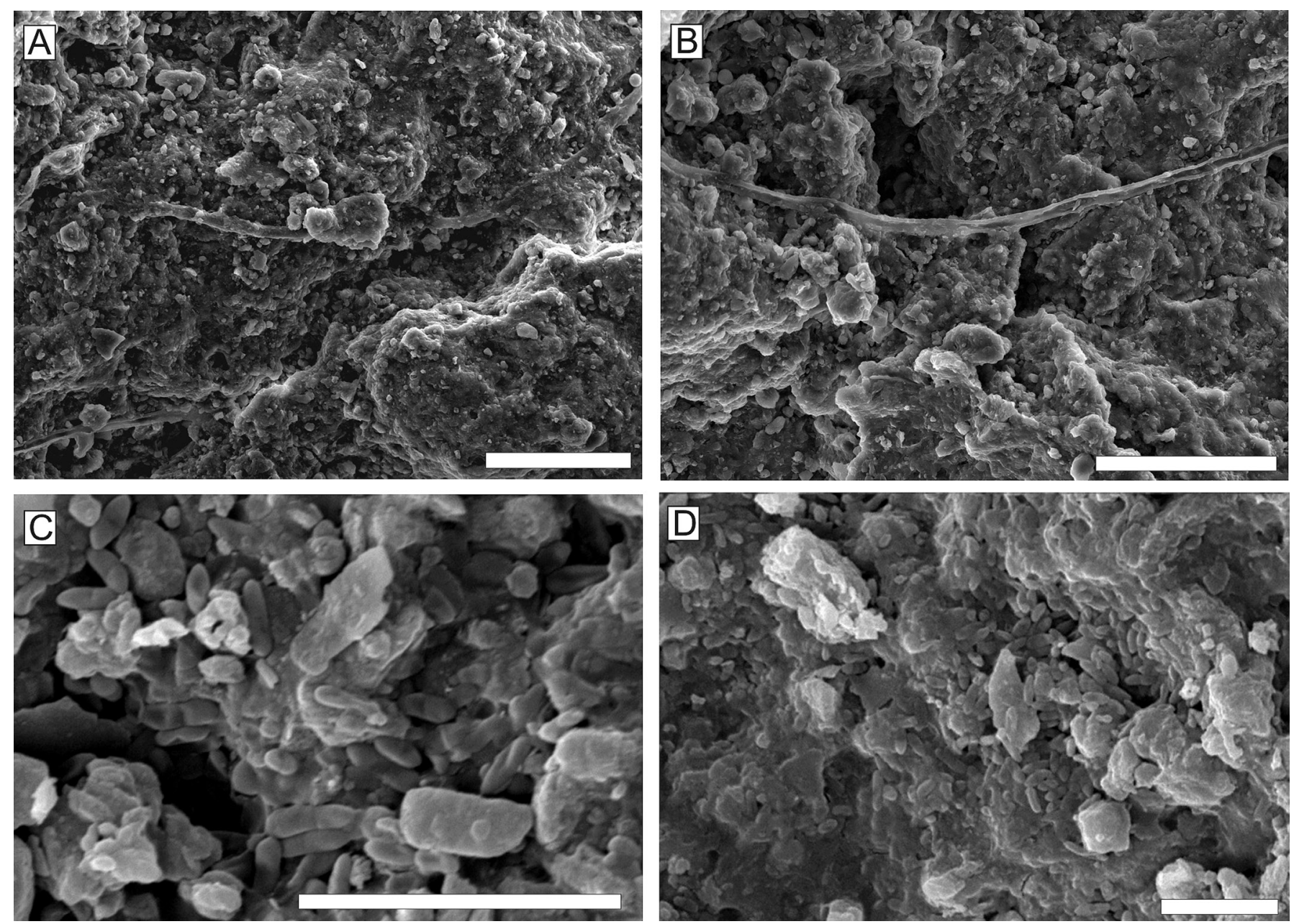

Figure 11. SEM images of microbial structures registered inside Fe-Mn macro-oncoids from the Lúgar-Corque Unit. A. and B. Straight cylindrical filaments branching without apparent pattern, probably corresponding to fungal hyphae. C. and D. Aggregates of bacillus-shaped bacteria. Scale-bar $=50 \mu \mathrm{m}$ in A and scale-bar $=10 \mu \mathrm{m}$ in $\mathrm{B}, \mathrm{C}$ and $\mathrm{D}$. 
f.- Biofilms with saclike structures: These are biofilms with cupuliform and saclike structures (4-7 $\mu \mathrm{m}$ in diameter) having spheric bodies (Figs. 16B, C). Many cupules are open and empty, and some spheres are accumulated close to the vessels of the biofilm. Moreover, filaments are close to these structures. The structures pertain to fungal sporangium (Alexopoulos et al., 1996).

The filamentous microbial remains built up the Mn crust, and some samples show several microbial laminae composed by superimposed filamentous meshworks (Figs. $13 \mathrm{~A}$ and 14A). Crystalline laminae may result from recrystallization of Mn oxides of the microbial laminae during diagenesis.

The negative results of the thin sections stained with DNA stains (DAPI and PI) allow us to rule out the presence of recent microbes in the samples studied from the Mn crust.

\section{INTERPRETATION}

Three different contexts of microbial crusts can be differentiated: surficial Fe-Mn crusts and macro-oncoids, cryptic Fe-Mn crusts and surficial Mn crusts.

\section{SURFICIAL Fe-Mn CRUSTS AND MACRO-ON- COIDS}

Martín-Algarra \& Sánchez-Navas (2000) and Reolid \& Nieto (2010) interpreted the precipitation of Jurassic FeMn crusts and macro-oncoids from the Subbetic in relation to the chemo-organotrophic behaviour of the benthic microbial communities. Iron oxides can form as a result of the direct metabolic activity of microbes, or else as a result of passive sorption and nucleation reactions (Fortin \& Langley, 2005). According to Dahanayake \& Krumbein (1986), iron-secreting microbial mats are predominantly
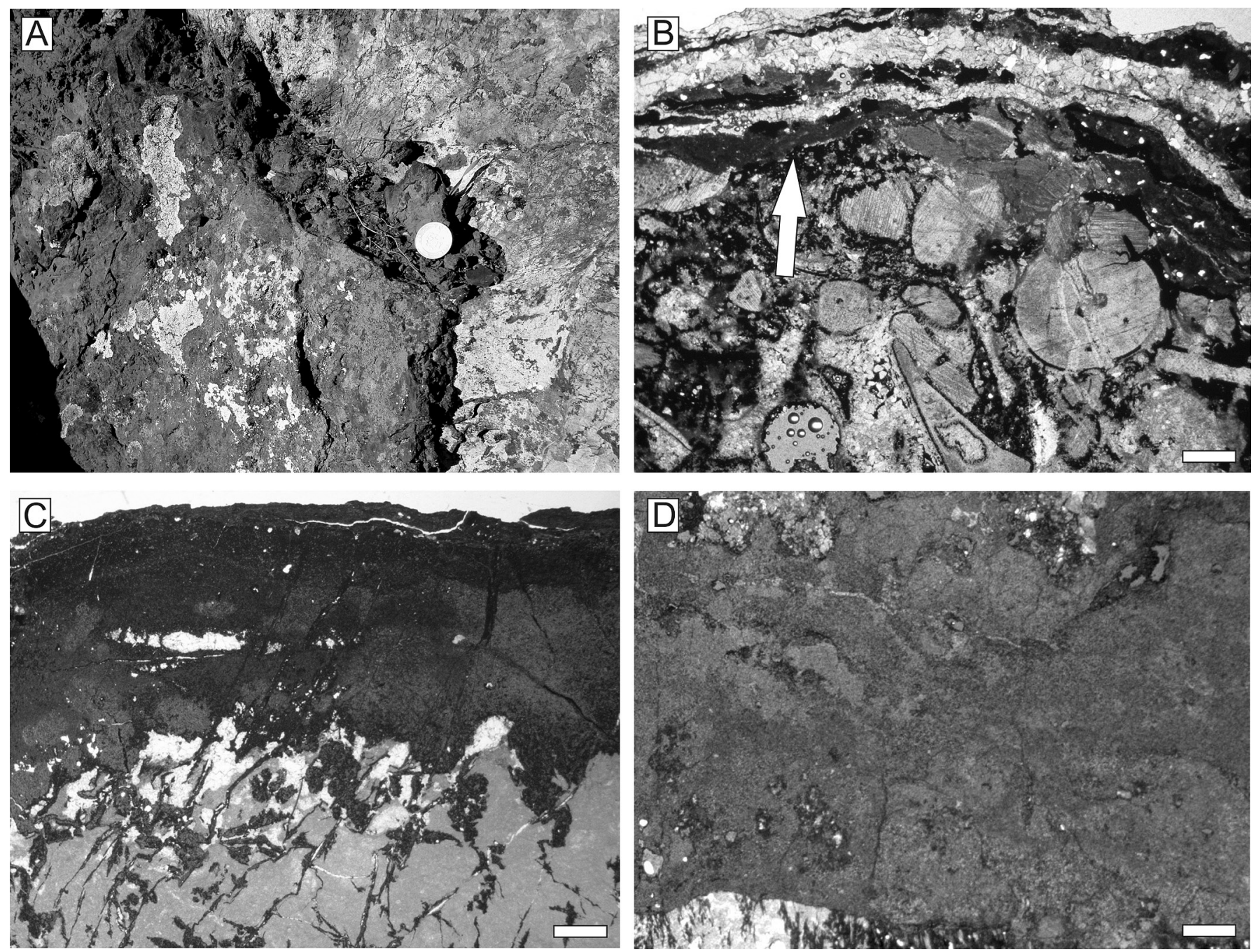

Figure 12. Manganesiferous crust of Ras Leona section (Jbel Moussa Group). A. Black crust of manganese over the unconformity surface. B. Contact between the crinoid limestone and the manganesiferous crust (white arrow). C. Manganesiferous crust with epigenic mineralizations advancing downward. D. Manganesiferous crust with no clear lamination. Scale-bar $=1 \mathrm{~mm}$. 
fungal in origin. However, fungi are heterotrophic organisms. Many authors have interpreted different types of eubacteria inducing Fe and Mn mineralizations (see Frankel \& Bazylinski, 2003). Fe- and Mn-oxidizing bacteria, both mesophilic autotrophic (such as Acidithiobacillus ferrooxidans and Leptospirillum sp.) and chemoheterotrophic bacteria (such as Sphaerotilus, Leptothrix and Siderocapsa) are known to induce the precipitation of Fe-Mn oxyhydroxides under acidic and neutral conditions where $\mathrm{Fe}^{3+}$ and $\mathrm{Mn}^{4+}$ are soluble (Southam, 2000; Frankel \& Bazylinski, 2003; Hanert, 2006). Moreover, the presence of Frutexites is commonly associated with Fe-Mn crusts, and they are interpreted as chemosynthetic and cryptobiontic microorganisms (Böhm \& Brachert, 1993; Chafetz et al., 1998; Cavalazzi et al., 2007).
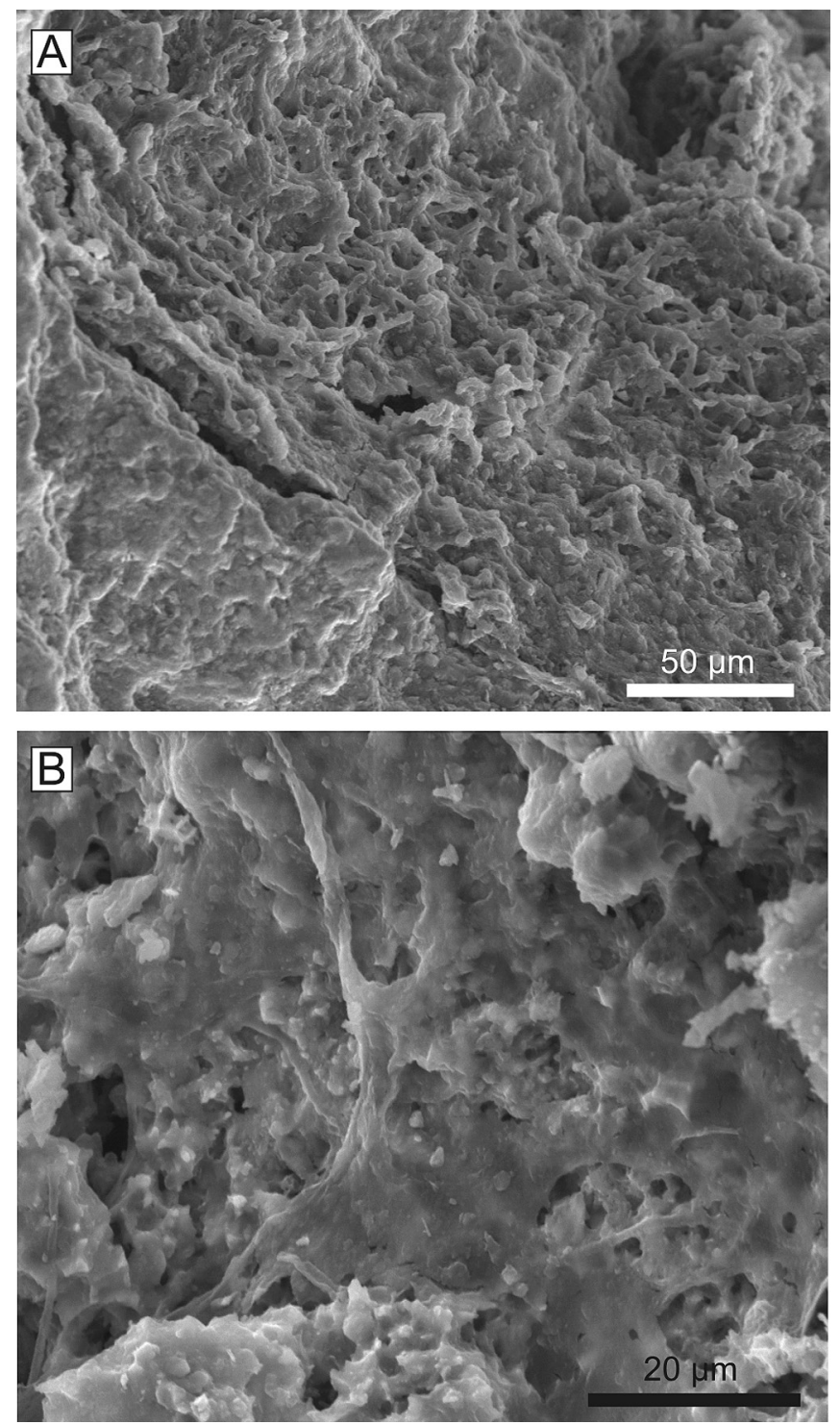

Figure 13. SEM images of microbial lamination. A. Tilted view of laminae composed by dense branched filamentous mats. B. Mineralized biofilm among filaments.
Noteworthy is the interpretation of the Mn content of the macro-oncoids. The origin of Mn-oxides may be related to inorganic and organic processes. However, inorganic precipitation mechanisms are considered to be insufficient for accretion of significant amounts of $\mathrm{MnO}$ in natural environments (Ostwald, 1990). It is well recognized that, in recent environments, efficient precipitation of $\mathrm{Mn}$ from natural water depends basically on the presence of Mn-oxidizing microbes (Nealson \& Stahl, 1997; Francis \& Tebo, 2002; Frankel \& Bazylinski, 2003). Some types of eubacteria can induce the precipitation of Mn-oxides 4 to 5 orders of magnitude more efective than by abiotic precipitation (Hasting \& Emerson, 1986; Francis \& Tebo, 2002). Monty (1973), Greenslate (1974), Ehrlich (1975) and Krumbein (1983) have suggested the influence of microbes in the reactions of $\mathrm{Mn}$ in deep-sea manganese nodules, whereas Schaefer et al. (2001) propose Mn precipitation that is biogenically controlled in shallow water oncoids.

Specific Fe and Mn enrichment by microbes highlights the importance of microbial biocoenoses as a catalyzer, also serving as a specific trap of these elements (Krumbein \& Jens, 1981; Nealson, 1983; Dahanayake \& Krumbein, 1986; Frankel \& Bazylinski, 2003). Iron and manganese are concentrated by extracellular traps in the microbial wall. In the studied macro-oncoids, the former existence of mucilaginous substances around the microbes and their role as an iron chelating compound (siderophore) secreted by microorganisms in the precipitation of authigenic minerals can be reasonably inferred by the presence of fibrillar meshworks. According to Lewin (1984), siderophores produced by microbes could trap and transfer $\mathrm{Fe}^{3+}$ into the cell interior. Authigenesis occurred by means of the Fe and Mn previously enriched by the siderophores as amorphous precursor phases that could later be precipitated as Fe-Mn oxyhydroxides. The Ce enrichment, in turn, might be adequately explained by oxidative scavenging of $\mathrm{Ce}^{4+}$ from normal seawater by $\mathrm{Fe}-\mathrm{Mn}$ oxyhydroxides formed in close genesis to microbes (Martín-Algarra \& Sánchez-Navas, 1995). The pelagic swells of the External Subbetic were favourable places for microbially mediated authigenesis due to: a) the sediment-starved conditions (e.g., Reolid et al., 2010), and b) the injection in seawater of $\mathrm{Fe}, \mathrm{Mn}$, trace elements, and REE related to the contemporary volcanic processes recorded in the Median Subbetic (Puga et al., 1989; Vera et al., 1997).

The existence of organisms in the Fe-Mn crusts and macro-oncoids, such as fungi and encrusting foraminifera, has palaeoecological implications. The association of encrusting foraminifera with microbial films closely resembles commensalism, where the biofilms served as a food source for the encrusting foraminifera and fungi, while the bacteria and fungi took advantage of the nutrient-rich foraminiferal excretions. Gradzinski et al. (2004) suggested this kind of relationship for the occurrence of nubeculariids and Tolypammina in microbial-foraminiferal oncoids 
in the Toarcian of the Tatra Mountains (Poland). Veillette et al. (2007) studied the sessile foraminifera from modern manganese nodules and surmised that food particles could be obtained either from suspension or from microbial films present on the nodule surface.

The plano-convex irregular shell of the encrusting foraminifera is generally attributed to a sessile epifaunal mode of life and passive herbivore or suspension-feeder strategy (Reolid et al., 2008). These forms cannot graze, and so must feed on organisms they harvest with their pseudopodia near the attachment site (Jones \& Charnock, 1985). According to Gooday \& Haynes (1983) and Lipps (1983), these passive herbivores presumably feed on bacteria. In Oxfordian deposits of the neighbouring Prebetic (Betic Cordillera), Placopsilina and Tolypammina are typi- cal encrusting taxa occurring in association with microbial fabrics and encrustations (Reolid et al., 2005; Reolid \& Gaillard, 2007).

\section{CRYPTIC Fe-Mn CRUSTS}

The walls of submarine cavities developed during the Middle-Late Jurassic unconformity in the Central External Subbetic were an appropriate place for colonization by serpulid-Frutexites assemblages growing downward from the top walls of the cavities. In the case of the neptunian dykes of the Eastern External Subbetic, the endostromatolites are composed by Frutexites but serpulids are absent.

The serpulids have been interpreted as epibionts with photophobic behaviour (Gaillard, 1983; Kobluk, 1988; Olóriz et al., 2002; Reolid et al., 2005). In anomalous-
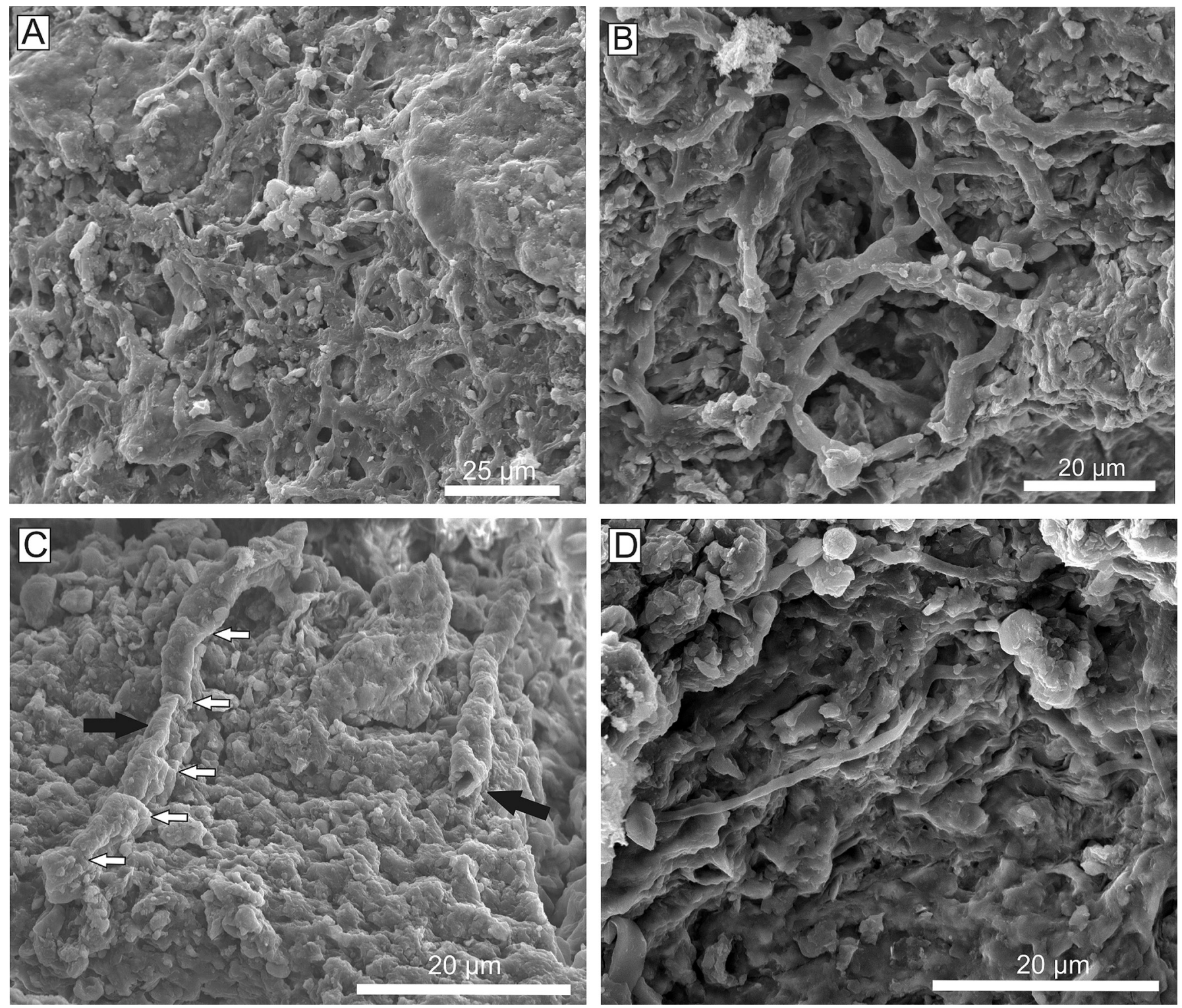

Figure 14. SEM images of filamentous structures. A. Lamination constituted by webs of filaments with dense dichotomous branching. B. Dense meshwork of thin, straight to slightly curved cylindrical filaments, with dichotomous branching. C. Rugose simple filaments (black arrows) with cellular cross walls (white arrows). D. Smooth simple filaments. 
ly stressed environments, serpulids have been described as the main constituent of buildups (Palma \& Angeleri, 1992; Friebe, 1994; Fornós et al., 1997; Cirilli et al., 1999; among others), possibly in conjunction with low oxygen, anomalous salinities, or eutrophic conditions. Recent serpulids are tolerant to low-oxygen bottom-water conditions (Sageman et al., 1991).

Microborers colonised the outer side of the serpulid tubes previous to Frutexites colonization. Similar authigenic precipitation of $\mathrm{Fe}$ and $\mathrm{Mn}$ oxyhydroxides is interpreted on Jurassic examples by Schlögl et al. (2008), and on modern hard surface fauna by Toscano \& Raspini (2005).

The presence of Frutexites is commonly associated with Fe-Mn oxyhydroxides (Wallace et al., 1991; Böhm \& Brachert, 1993; Nicoll \& Playford, 1993; Mamet \& Préat, 2006; Cavalazzi et al., 2007; Reolid \& Nieto, 2010). The type of microbe involved in Frutexites, however, is unclear and has frequently been assigned a cyanobacterial origin (Walter \& Awramik, 1979; Riding, 1991; Nicoll \& Playford, 1993) or interpreted as a chemosynthetic and cryptobiontic microorganism (Böhm \& Brachert, 1993; Chafetz et al., 1998; Mišík \& Aubrecht, 2004; Cavalazzi et al., 2007; Reolid \& Nieto, 2010). The record of Frutexites is congruent with scarce light availability. Böhm \& Brachert (1993) related the record of Frutexites with aphotic stromatolites and evoked a non-phototrophic behaviour in Jurassic examples from Germany. Myrow \& Coniglio (1991), Böhm \& Brachert (1993) and Cavalazzi et al. (2007) have interpreted a cryptobiontic lifestyle for the organisms producing Frutexites. Böhm \& Brachert (1993), in the particular case of Frutexites, interpret a preference for oxygen deficient environments. The record of bacterial and fungal communities related to $\mathrm{Fe}-\mathrm{Mn}$ crusts in modern examples from submarine caves in the northwestern Mediterranean (Allouc \& Harmelin, 2001), and from reef caves at Lizard Island in Great Barrier Reef (Reitner et al., 2000), serve to confirm the growth of such Fe-Mn coatings in reduced light conditions.

The sessile foraminifera, as minor components in this assemblage, are congruent with the cryptobiontic behaviour inferred by the serpulids and Frutexites. The most abundant is Bullopora tuberculata, which was reported previously to be a common inhabitant of cryptic microhabitats (Olivier, 2004; Reolid \& Gaillard, 2007). Another foraminifera of this assemblage is Tolypammina, which is very common in sheltered parts of bioclasts or inside microborings, Bullopora and Thurammina chambers, and spicule meshes of hexactinellid sponges (Kazmierczak, 1973; Gaillard, 1983; Olóriz et al., 2004; Guibault et al., 2006; Reolid, 2007; Reolid \& Gaillard, 2007; RodríguezMartínez et al., 2011). A similar habitat was described for T. gregaria by Benjamini (1984) from the Anisian of Israel. Tolypammina and Thurammina were interpreted by Reolid \& Gaillard (2007) as cryptobiontic microorganisms. The sessile foraminifera are usually found colonizing the serpulid tubes and the Frutexites shrubs, and the shape of the foraminiferal tests are adapted to the topography of these types of substrates. This indicates a succession in the cavity-dwelling fauna in which the colonisers were the serpulids, whereas sessile foraminifera appeared in more advanced phases. The overgrowing specimens often attached to already mineralized and encrusted tubes might indicate that the authigenic mineralization occurred at a time around aggregate formation. Moreover, the colonization of Frutexites by sessile foraminifera excludes the possibility of a diagenetic origin of Frutexites.
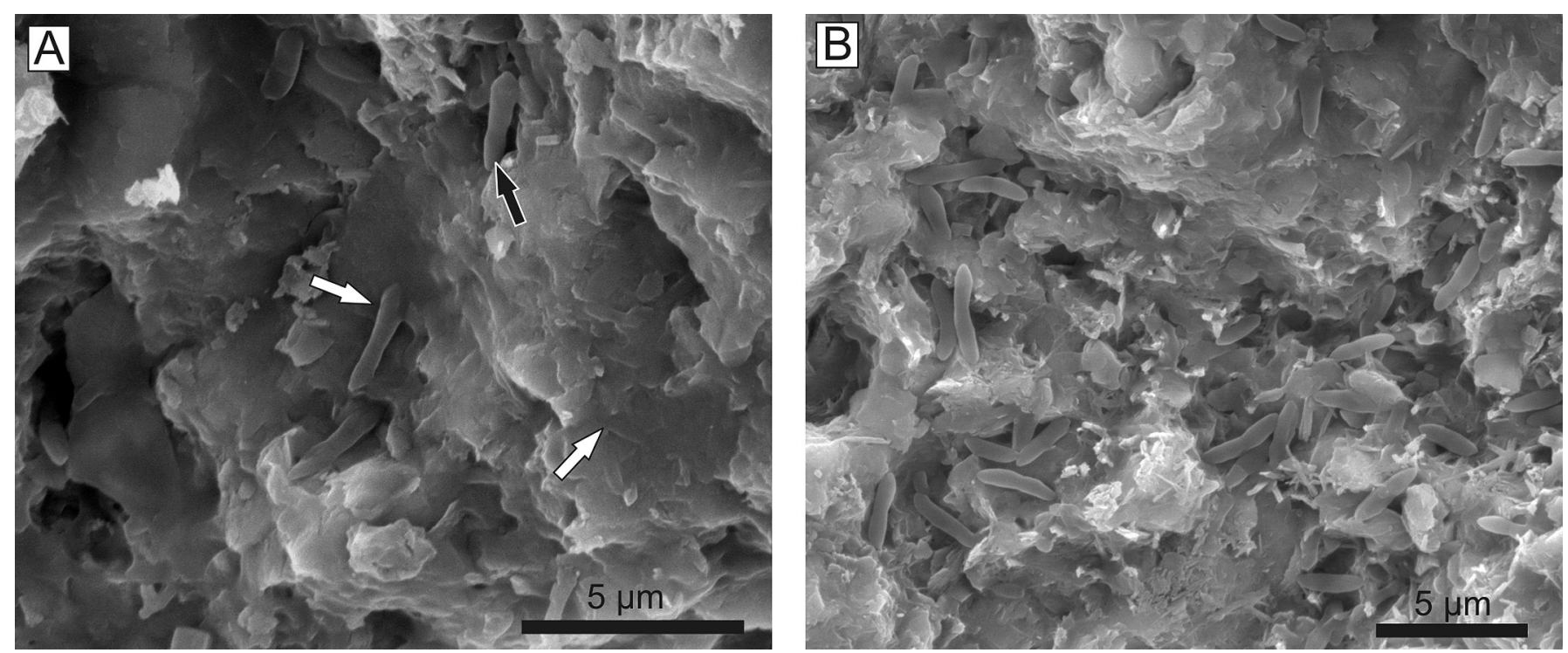

Figure 15. Bacillus-shaped microbes. A. Microbes with morphology of bacillus locally fused with the Mn crust (white arrow) and bacillus well preserved (black arrow) show that these forms were probably undetectable under thin section. B. Very well preserved bacillus. 


\section{SURFICIAL Mn CRUSTS}

The mineralogy and geochemistry of the studied $\mathrm{Mn}$ crust from the Jbel Moussa (Rifian Calcareous Chain) are congruent with a hydrothermal origin (Reolid et al., 2011). According to Glasby (2000) the hydrothermal Mn-crusts in modern oceans are characterised by low contents (in ppm) of $\mathrm{Cu}(20-1000), \mathrm{Ni}(1-1400), \mathrm{Zn}(1-1230), \mathrm{Co}(6-210)$, and $\mathrm{Pb}(0-93 \mathrm{ppm})$. The manganese crust from the Ras Leona section presents values (in $\mathrm{ppm}$ ) within the hydrothermal range for these elements $(\mathrm{Cu}=201, \mathrm{Ni}=131, \mathrm{Zn}$ $=95, \mathrm{Co}=87$, and $\mathrm{Pb}=2$ ).

$\mathrm{Mn} / \mathrm{Fe}$ ratio exceeding 40 is typical of hydrothermal manganese precipitates (Corliss et al., 1978; Bolton et al., 1988; Usui et al., 1997). According to Glasby (2000), the hydrothermal manganese crusts in modern oceans can have $\mathrm{Mn} / \mathrm{Fe}$ ratios from 10 to 4670 . In the studied manganese crust the $\mathrm{Mn} / \mathrm{Fe}$ ratio is 87 . Positive Ce anomaly and high $\sum$ REE are characteristics of hydrogenetic and hydrogenetic-diagenetic manganese crusts, while a negative $\mathrm{Ce}$ anomaly along with a positive $\mathrm{Eu}$ anomaly and low $\sum$ REE are characteristics of hydrothermal manganese crusts (Matsumoto et al., 1985; Mills \& Eldefield, 1995; Hein et al., 1997; Usui et al., 1997; Kuhn et al., 1998). The values of $\sum$ REE in hydrogenetic manganese crusts exceed 1400 ppm (Hein et al., 1997), whereas they are about 100 ppm or less in hydrothermal manganese deposits (Usui et al., 1997). In the studied crust $\sum$ REE is $10 \mathrm{ppm}$, and there are negative $\mathrm{Ce}$ and positive Eu anomalies in PAAS-nor-
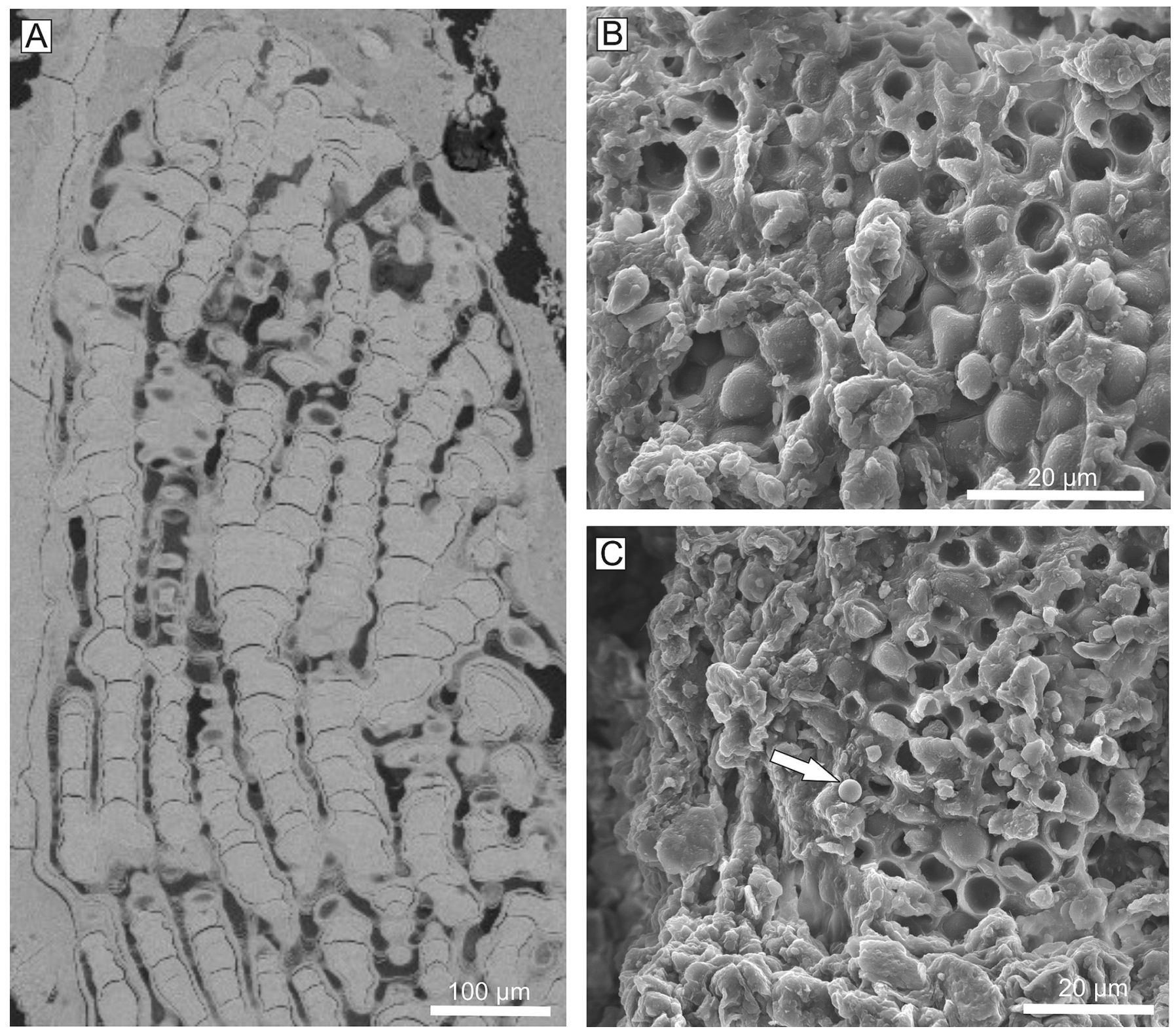

Figure 16. SEM images of the less commom microbial structures in the Mn crust of Ras Leona section. A. Bunches of segmented and branched filaments from thin section (back-scattered images). B. Biofilms with saclike structures in the surface resembling fungal sporangium. C. Biofilm with a microsphere (white arrow), probably a fungal spore. 
malised patterns. High Eu anomalies in the deposits reflect a process of leaching of $\mathrm{Eu}^{2+}$ from the host rocks at temperatures above $250^{\circ} \mathrm{C}$. Enrichment in light REE relative to heavy REE is also characteristic of hydrothermal origin (Mills \& Eldefield, 1995). The identified minerals (Ca-birnessite, cryptomelane, and coronadite) have been reported in hydrothermal vent deposits (Lonsdale et al., 1980; Glasby et al., 2005; Canet \& Prol-Ledesma, 2007). Birnessite has been interpreted in relation to hydrothermal metal-enriched solutions (Koschinsky \& Hein, 2003; Canet et al., 2008) and sometimes related to cryptomelane (Corona-Esquivel et al., 2000). Birnessite is a biologicalinduced Mn mineral (Frankel \& Bazylinski, 2003) that is poorly crystalline and a common component of the fossil microbial filaments. Coronadite has been reported in deposits related to hydrothermal vents and vein deposits (Glasby et al., 2005; Canet \& Prol-Ledesma, 2007; Camprubí et al., 2008).

In the context of this research, the record of benthic microbial communities is compatible with the hydrothermal origin of the Mn crust. Modern microbialites occur abundantly in the vicinity of submarine hydrothermal vents, which are the source of nutrients for microbes. Microbes that precipitate $\mathrm{Mn}$ oxides and iron compounds have been described in such environments (Ghiorse \& Ehrlich, 1992; Mandernack \& Tebo, 1993; Ehrlich, 1996; Connell et al., 2009; Santelli, 2009; Templeton et al., 2009). The precipitation of manganese minerals is interpreted as induced by the chemo-organotrophic behaviour of benthic microbial communities, since manganese oxides may form as a result of the direct metabolic activity of microbes (Ehrlich, 1996; Chafetz et al., 1998; Frankel \& Bazylinski, 2003). Many authors have interpreted different types of eubacteria inducing Fe and Mn mineralizations (see Frankel \& Bazylinski, 2003). However, we interpret the main filamentous structures observed in SEM images as fungal hyphae, also described in hydrothermal environments (Connell et al., 2009). The presence of ascomycetes is congruent with the recognition of these fungi in recent deep-sea hydrothermal ecosystems (Le Calvez et al., 2009). Less common components such as the aggregates of bacillus-shaped forms are very probably related to eubacteria; and their association with the Mn oxidation cannot be ruled out in view of their importance in the precipitation of Mn crusts in hydrothermal environments (Mandernack \& Tebo, 1993; Dick et al., 2009). Fungi most likely feed on bacterial communities and their by-products.

In modern environments, it is known that efficient precipitation of Mn from sea water depends basically on the presence of Mn-oxidizing microbes (Peck, 1986; Nealson \& Stahl, 1997; Francis \& Tebo, 2002; Frankel \& Bazylinski, 2003). Some types of bacteria (like some Bacillus species, among others) can increase the rates of precipitation of Mn-oxides up to 4 to 5 orders of magnitude with respect to abiotic precipitation (Hasting \& Emerson,
1986; Chafetz et al., 1998; Francis \& Tebo, 2002). Ehrlich (1975) and Krumbein (1983) envisaged the influence of microbes in the reactions of $\mathrm{Mn}$ in deep-sea manganese nodules. An important source of $\mathrm{Mn}$ in marine environments is the hydrothermal activity associated with global tectonic processes (Corbin et al., 2000; Rojkovič et al., 2003). In hydrothermal vents, a high microbial activity has been described, involving microbes that enhance the scavenging of $\mathrm{Mn}$, facilitating its deposition (Mandernack \& Tebo, 1993). Precipitation could be related to increasing $\mathrm{pH}$ and Eh created in the microenvironment around microbial clumps: oxidizing and alkaline conditions would have favoured the precipitation of Mn (e.g., Rankama \& Sahama, 1960, Chafetz et al., 1998). Microbially induced Mn enrichment highlights the importance of microbial biocoenoses as a catalyzer, also serving as a specific trap of these elements (Krumbein \& Jens, 1981; Frankel \& Bazylinski, 2003). In the studied crusts, the existence of mucilaginous biofilms around the microbes and their role as a manganese chelating compound secreted by microorganisms in the precipitation of authigenic minerals can be reasonably inferred by the occurrence of microbial microstructures. Authigenesis occurred through the Mn that had been previously enriched as amorphous precursor phases, and later precipitated as manganese oxides.

\section{CONCLUSIONS}

The Middle-Upper Jurassic transition in the External Subbetic (Betic Cordillera) and the Jbel Moussa Group (Rifian Calcareous Chain) is characterised by numerous stratigraphic breaks recorded as hardgrounds with microbial Fe-Mn crusts. Three different contexts of microbial crusts can be differentiated:

a) Surficial Fe-Mn crusts and macro-oncoids. They are hydrogenetic crusts related to the chemo-organotrophic behaviour of benthic microbial communities. Microbial biocoenoses served as a specific trap for Fe and Mn enrichment. The record of encrusting foraminifera (Thurammina, Placopsilina, Tolypammina and nubeculariids) and fungi with microbial films closely resembles commensalism, where the biofilms served as a food source for the encrusting foraminifera and fungi, while bacteria and fungi took advantage of the nutrient-rich foraminiferal excretions. The surficial Fe-Mn crusts and macro-oncoids developed in pelagic swells of the External Subbetic because microbially mediated authigenesis was favoured by the overall sediment-starved conditions, as well as the injection in seawater of $\mathrm{Fe}, \mathrm{Mn}$, trace elements and REE related to contemporaneous volcanic processes recorded in the Median Subbetic.

b) Cryptic Fe-Mn crusts: They are hydrogenetic crusts with the same mineralogy and geochemistry as the surficial Fe-Mn crusts, but they grew in the walls of submarine 
cavities and fractures. They are endostromatolites constituted almost exclusively by Frutexites in the case of thin neptunian dykes, or by serpulid-Frutexites assemblages growing downward from the top walls of large neptunian sills. This assemblage reflects the colonization of an unfavourable environment (aphotic and probably low oxygenation) as a response to photophobic behaviour. Frutexites is usually interpreted as a chemosynthetic and cryptobiontic microorganism. The record of sessile foraminifera such as Bullopora, Tolypammina and Thurammina is interpreted in the same sense as in the surficial Fe-Mn crusts and macro-oncoids.

c) Hydrothermal Mn crusts: bacillus-shaped bacteria and different types of filaments are identified in Mn crusts, with mineralogy and geochemistry pointing to a hydrothermal origin. A submarine hydrothermal vent is interpreted, where the precipitation of manganese minerals would be induced by the chemo-organotrophic behaviour of benthic microbial communities, since manganese oxides may form as a result of the direct metabolic activity of bacteria. The best preserved microbial structures are filaments interpreted as fungal hyphae, probably ascomycetes. It is probable that the fungi feed on bacterial communities and their by-products.

\section{ACKNOWLEDGEMENTS}

This research was carried out with financial support of the projects UJA_07_16_23 (Universidad de Jaén) and RYC-200904316 (Contrato Programa Ramón y Cajal, Fondo Europeo de Cohesión). We would like to thank Antonio Piedra (Technician of the Geologic Laboratory of Universidad de Jaén) for preparing the thin sections, Prof. Isabel Abad (Universidad de Jaén) for helping with XRD, and Profs. Luis M. Nieto, José M. Molina (Universidad de Jaén) and Khalil El Kadiri (Université Abdelmalek Esâadi Tetouan) for collaboration with the stratigraphic framework. The author thanks to Alain Préat (Université Libre de Bruxelles) and Joachim Reitner (Universität Göttingen) for their careful reviews of the manuscript and suggest for future research. The author is grateful to Jean Louise Sanders for reviewing the grammar.

\section{REFERENCES}

Alexopoulos, C.J., Mims, C.W. \& Blackwell, M. 1996. Introductory Mycology. John Wiley \& Sons Inc., Toronto, $869 \mathrm{pp}$.

Allouc, J., \& Harmelin, J.G. 2001. Les dépôts d'enduits manganoferrifères en environnement marin littoral. L'exemple de grottes sous-marines en Méditerrée nord-occidentale. Bulletin de la Société Géologique France, 172, 765-778.

Aurell, M., Badenas, B., Bello, J., Delvene, G., Meléndez, G., Pérez-Urresti, I. \& Ramajo, J. 1999. El Calloviense y el Jurasico Superior en la Cordillera Ibérica Nororiental y la zona de enlace con la Cordillera Costero Catalana, en los sectores de Sierra de Arcos, Calanda y Xerta-Paüls. Cuadernos de Geología Ibérica, 25, 73-110.

Aurell, M., Fernández-López, S. \& Meléndez, G. 1994. The Middle-Upper Jurassic oolitic ironstone level in the Iberian Range (Spain). Eustatic implications. Geobios M.S., 17, 549-561.

Benjamini, C. 1984. Foraminifera from the Ra'af Formation (Anisian), Har'areif, western Negev, Israel. Bulletin Centre Recherche Exploration-Production Elf-Aquitaine, 6, 35-40.

Böhm, F. \& Brachert, T.C. 1993. Deep-water stromatolites and Frutexites Maslov from the Early and Middle Jurassic of S-Germany and Austria. Facies, 28, 145-168.

Bolton, B.R., Both, R., Exon, N.F., Hamilton, T.F., Ostwald, J. \& Smith, J.D. 1988. Geochemistry and mineralogy of seafloor hydrothermal and hydrogenetic Mn oxide deposits from the Manus Basin and Bismarck Archipelago region of the southwest Pacific Ocean. Marine Geology, 85, 65-87.

Burne, R.V. \& Moore, L.S. 1987. Microbialites: Organosedimentary deposits of benthic microbial communities. Palaios, 2, 241-254.

Camprubí, A., Canet, C., Rodríguez-Díaz, A.A., ProlLedesma, R.M., Blanco-Florido, D., Villanueva, R.E. \& López-Sánchez, A. 2008. Geology, ore deposits and hydrothermal venting in Bahía Concepción, Baja California Sur, Mexico. Island Arc, 17, 6-25.

Canet, C. \& Prol-Ledesma, R.M. 2007. Mineralizing processes at shallow submarine hydrothermal vents: examples from México. Geological Society of America Spec. Papers, 422, 359-376.

Canet, C., Prol-Ledesma, R.M., Bandy, W.L., Schaaf, P., Linares, C., Camprubí, A., Tauler, E. \& Mortera-Gutiérrez, C. 2008. Mineralogical and geochemical constraints on the origin of ferromanganese crusts from the Rivera Plate (western margin of Mexico). Marine Geology, 251, 47-59.

Cavalazzi, B., Barbieri, R. \& Ori, G.G. 2007. Chemosynthetic microbialites in the Devonian carbonate mounds of Hamar Laghdad (Anti-Atlas, Morocco). Sedimentary Geology, 200, 73-88.

Chafetz, H.S., Akdim, B., Julia, R. \& Reid, A. 1998. Mn- and Fe-rich black travertine shrubs: bacterially (and nanobacterially) induced precipitates. Journal of Sedimentary Research, 68, 404-413.

Cirilli, S., Iannace, A., Jadoul, F. \& Zamparelli, V., 1999, Microbial-serpulid build-ups in the Norian-Rhaetian of the Western Mediterranean area: ecological response of shelf margin communities to stressed environments. Terra Nova, 11, 195-202.

Collin, P.Y., Loreau, J.P. \& Courville, P. 2005. Depositional environments and iron ooids formation in condensed sections (Callovian-Oxfordian, south-eastern Paris basin, France). Sedimentology, 52, 969-985.

Connell, L., Barret, A., Templeton, A. \& Staudigel, H. 2009. Fungal diversity associated with Active Deep Sea Volcano: Vailulu'u Seamount, Samoa. Geomicrobiology Journal, 26, 597-605.

Corbin, J.C., Person, A., Iatzoura, A., Ferré, B. \& Renard, M. 2000. Manganese in pelagic carbonates: indication of 
major tectonic events during the geodynamic evolution of a passive continental margin (the Jurassic European Margin of the Tethys-Ligurian Sea). Palaeogeography, Palaeoclimatology, Palaeoecology, 156, 123-138.

Corliss, J.B., Lyle, M., Dymond, J. \& Crane, K., 1978. The chemistry of hydrothermal mounds near Galapagos Rift. Earth Planetary Science Letters, 40, 12-24.

Corona-Esquivel, R., Ortega-Gutiérrez, F., Reyes-Salas, M., Lozano-Santacruz, R. \& Miranda-Gasca, M.A. 2000. Mineralogical study of the La Hueca Cretaceous ironmanganese deposit, Michoacán, Southwestern Mexico. Revista Mexicana de Ciencias Geológicas, 17, 143-153.

Courville, P. \& Collin, P.Y. 1997. La série du Callovien et de l'Oxfordien de Veuxhaulles (Châtillonnais, Côte d'Or): problèmes de datation, de géométrie et de paléoenvironnements dans une série "condensée". Bulletin Sciences Bourgogne, 49, 29-43.

Dahanayake, K. \& Krumbein, W.E. 1986. Microbial structures in oolitic iron formations. Mineralium Deposita, 21, 85-94.

Dick, G.J, Clement, B.G., Webb, S.M., Fodrie, F.J., Bargar, J.R. \& Tebo, B.M. 2009. Enzymatic microbial Mn(II) oxidation and Mn biooxide production in the Guaymas Basin deep-sea hydrothermal plume. Geochimica et Cosmochimica Acta, 73, 6517-6530.

Durand-Delga, M. 1972. La courbure de Gibraltar, extrémité occidentale des chaînes alpines, unit l'Europe et l'Afrique. Eclogae Geologicae Helvetiae, 65, 267-278.

Durand-Delga, M. \& Villiaumey, M. 1963. Sur la stratigraphie et la tectonique du Groupe du Jbel Musa (Rif septentrinal, Maroc). Bulletin de la Société Géologique de France, 5, 70-79.

Ehrlich, H.L. 1975. The formation of ores in the sedimentary environment of the deep sea with microbial participation: The case for ferromanganese concretions. Soil Science, 119, 36-41.

Ehrlich, H.L. 1996. Geomicrobiology of manganese. In: Geomicrobiology (Ed. H.L. Ehrlich). New York, Marcel Dekker, 389-489.

El Hatimi, N. 1991. Rifting mésozö̈que sur la bordure occidentale du Rif Interne (Maroc). Evolution géodynamique d'un secteur de la marge oust-téthysienne. Exemples du Haouz et du Jbel Moussa. PhD Thesis Université Pau, 301 pp.

El Kadiri, K. 1991. La Dorsale Calcaire (Rif Interne, Maroc): stratigraphie, sédimentologie etévolution géodynamique d'une marge alpine durant le Mésozoïque. Mise en evidence d'un modèle. PhD Thesis Université Tétouan, 400 pp.

El Kadiri, K. 2002. Jurassic ferruginous hardgrounds of the "Dorsale Calcaire" and the Jbel Moussa Group (Internal Rif, Morocco): Stratigraphical context and paleoceanographic consequences of mineralization processes. Geologica Romana, 36, 33-69.

El Kadiri, K., Linares, A. \& Olóriz, F. 1990. Les éléments du Groupe du Jbel Moussa (Chaîne Calcaire, Rif, Maroc): évolutions stratigraphique el géodynamique au cours du Jurassique-Crétacé. Comunicações dos Serviços Geológicos de Portugal, 76, 141-161.
Fornós, J.J., Forteza, V. \& Martínez-Taberner, A. 1997. Modern polychaete reefs in Western mediterranean lagoons: Ficopomatus enigmaticus (Fauvel) in the Albufera of Menorca, Balearic Islands. Palaeogeography, Palaeoclimatology, Palaeoecology, 128, 175-186.

Fortin, D. \& Langley, S. 2005. Formation and occurrence of biogenic iron-rich minerals. Earth-Science Reviews, 72, 1-19.

Francis, C.A. \& Tebo, B.M. 2002. Enzymatic manganese (II) oxidation by metabolically dormant spores of diverse $\mathrm{Ba}$ cillus species. Applied and Environmental Microbiology, 68, 874-880.

Frankel, R.B. \& Bazylinski, D.A. 2003. Biologically induced mineralization by bacteria. Reviews in Mineralogy and Geochemistry, 54, 95-114.

Friebe, J.G. 1994. Serpulid-bryozoan-foraminiferal biostromes controlled by temperate climate and salinity: Middle Miocene of Styrian Basin, Austria. Facies, 30, 51-62.

Gaillard, C. 1983. Les biohermes à spongiaires et leur environment dans l'Oxfordian du Jura méridional. Documents Laboratoires Géologie Lyon, 90, 515 pp.

García-Hernández, M., López-Garrido, A.C., Rivas, P., Sanz de Galdeano, C. \& Vera, J.A. 1980. Mesozoic paleogeographic evolution of the External Zones of the Betic Cordillera. Geologie en Minjbow, 59, 155-168.

García-Hernández, M., López-Garrido, A.C., Martín-Algarra, A., Molina, J.M., Ruiz-Ortiz, P.A. \& Vera, J.A. 1989. Las discontinuidades mayores del Jurásico de las Zonas Externas de las Cordilleras Béticas: análisis e interpretación de los ciclos sedimentarios. Cuadernos de Geología Ibérica, 13, 35-52.

Gerdes, G., Klenke, T. \& Nofke, N. 2000. Microbial signatures in peritidal siliciclastic sediments: a catalogue. Sedimentology, 47, 279-308.

Ghiorse, W.C. \& Ehrlich, H.L. 1992. Microbial biomineralization of iron and manganese. In: Biomineralization. Processes of Iron and Manganese Modern and Ancient Environments (Eds. H.C.W. Skinner \& R.W. Fitzpatrick). Catena, 21, 75-99.

Glasby, G.P. 2000. Manganese: Predominant role of nodules and crusts. In: Marine geochemistry (Eds. H.D. Schultz \& M. Zabel). Springer, Heidelberg-New York, 35-372.

Glasby, G.P., Papavassiliou, C.T., Mitsis, J., Valsani-Jones, E., Liakopoulos, A. \& Renner, R.M. 2005. The Vani manganese deposits, Milos Island, Greece: A fossil stratabound $\mathrm{Mn}-\mathrm{Ba}-\mathrm{Pb}-\mathrm{Zn}$-As-Sb-W-rich hydrothermal deposit. Development in Volcanology, 7, 255-291.

Gooday, A.J. \& Haynes, J.R. 1983. Abyssal foraminifers, including two new genera, encrusting the interior of $\mathrm{Ba}$ thysiphon rusticus tubes. Deep-sea Research, 30, 591-614.

Gradzinski, M., Tyszka, J., Uchman, A. \& Jach, R. 2004. Large microbial-foraminiferal oncoids from condensed Lower-Middle Jurassic deposits a case study from the Tatra Mountains, Poland. Palaeogeography, Palaeoclimatology, Palaeoecology, 213, 133-151.

Greenslate, J. 1974. Microorganisms participate in the construction of manganese nodules. Nature, 249, 181-183.

Guerrera, F., Martín-Algarra, A. \& Perrone, V. 1993. Late Oligocene-Miocene syn-/-late-orogenic successions in 
Western and central Mediterranean Chains from the betic Cordillera to the Southern Apennines. Terra Nova, 5, 525-544.

Guibault, J.P., Krautter, M., Conway, K.W. \& Barrie, J.V. 2006. Modern foraminifera attached to hexactinellid sponge meshwork on the West Canadian Shelf: comparison with Jurassic counterparts from Europe. Palaeontologia Electronica, 9, 48 pp. http://palaeo-electronica.org/paleo/2006 $1 /$ sponge/issue $6 . \mathrm{htm}$

Gygi, R.A. 1981. Oolitic iron formations: marine or not marine? Eclogae Geologicae Helvetiae, 74, 233-254.

Gygi, R.A. \& Persoz, F. 1987. The epicontinental sea of Swabia (southern Germany) in the Late Jurassic: factors controlling sedimentation. Neues Jahrbuch für Geologie und Paläontologie Abhandlungen, 176, 49-65.

Han, X., Jin, X., Yang, S., Fietzke, J. \& Eisenhauer, A. 2003. Rhythmic growth of Pacific ferromanganese nodules and their Milankovitch climatic origin. Earth and Planetary Science Letters, 211, 143-157.

Hanert, H.H. 2006. The genus Siderocapsa (and other ironand manganese-oxidizing eubacteria). Prokaryotes, 7 , 1005-1015.

Hasting, D. \& Emerson, S. 1986. Oxidation of manganese by spores of a marine bacillus: kinetic and thermodynamic considerations. Geochimica and Cosmochimica Acta, 50, 1819-1824.

Hein, J.R., Koschinsky, A., Halbach, P., Manheim, F.T., Bau, M., Kang, J.K. \& Lubick, N. 1997. Iron and manganese oxide mineralization in the Pacific. In: Manganese Mineralization: geochemistry and Mineralogy of terrestrial and marine deposits (Eds. K. Nicholson, J.R. Hein, B. Bühn \& S. Desgupta). Geological Society Special Publication, 119, 123-138.

Hofmann, H.J. \& Grotzinger, J.P. 1985. Shelf-facies microbiotas from the Odjick and Rocknest foramtions (Epworth Group; $1.89 \mathrm{Ga}$ ), northwesttern Canada. Canadian Journal of Earth Sciences, 30, 1781-1792.

Huber, B., Müller, B. \& Luterbacher, H. 1987. Mikropaläontologische Untersuchungen an der Callovien/Oxfordien-Grenze im Schweizer Jura und auf der Schwäbischen Alb (vorläufige Mitteilung). Eclogae Geologicae Helvetiae, 80, 449-459.

Jach, R. \& Dudek, T. 2005. Origin of Toarcian manganese carbonate/silicate deposits from the Krížna unit, Tatra Mountains, Poland. Chemical Geology, 224, 136-152.

Jiménez-Espinosa, R., Jiménez-Millán, J. \& Nieto, L.M. 1997. Factors controlling the genesis of Fe-Mn crusts in stratigraphic breaks of the eastern Betic Cordillera (SE Spain) deduced from numerical analysis of geological data. Sedimentary Geology, 114, 97-107.

Jiménez-Millán, J. \& Nieto, L.M. 2008. Geochemical and mineralogical evidence of tectonic and sedimentary factors controlling the origin of ferromanganese crusts associates to stratigraphic discontinuities (Betic Cordilleras, SE of Spain). Chemie der Erde, 68, 323-336.

Jones, R.W. \& Charnock, M.A. 1985. "Morphogroups" of agglutinating foraminifera. Their life position and feeding habits and potential applicability in (paleo)ecological studies. Revue de Paléobiologie, 4, 311-320.
Kazmierczak, J. 1973. Tolypammina vagans (Foraminiferida) as inhabitant of the Oxfordian siliceous sponges. Acta Paleontologica Polonica, 18, 95-115.

Kobluk, D.R. 1988, Cryptic faunas in reefs: ecology and geologic importance. Palaios, 3, 379-390.

Koschinsky, A. \& Hein, J.R. 2003. Uptake of elements from seawater by ferromanganese crusts: solid-phase association and seawater speciation. Marine Geology, 198, 331-351.

Krumbein, W.E. 1983. Microbial geochemistry. Blackwell Scientific Publisher, London, 330 pp.

Krumbein, W.E. \& Jens, K. 1981. Biogenic rock varnishes of the Negev Desert (Israel), an ecological study of iron and manganese transformation by cyanobacteria and fungi. Oecologia, 50, 25-38.

Kuhn, T., Bau, M., Blum, N. \& Halbach, P. 1998. Origin of negative $\mathrm{Ce}$ anomalies in mixed hydrothermal-hydrogenetic Fe-Mn crusts from the central Indian Ridge. Earth and Planetary Science Letters, 163, 207-220.

Le Calvez, T., Burgaud, G., Mahé, S., Barbier, G. \& Vandenkoornhuyse, P. 2009. Fungal diversity in deep-sea hydrothermal ecosystem. Applied and Environmental Microbiology, 75, 6415-6421.

Lewin, R. 1984. How microorganisms transport iron. Science, 225, 401-402.

Lipps, J.H. 1983. Biotic interactions in benthic foraminifera. In: Biotic interaction in modern and fossil benthic communities (Eds. M.J.S. Tevesz, \& P.L. McCall). Plenum Press, New York, 331-376.

Lonsdale, P., Burns, V.M. \& Fisk, M. 1980. Nodules of hydrothermal birnessite in the caldera of a young seamount. Journal of Geology, 88, 611-618.

Lorin, S., Courville, P., Collin, P.Y., Thierry, J. \& Tort, A. 2004. Modalités de réinstallation d'une plate-forme carbonatée après une crise sédimentaire: exemple de la limite Oxfordien moyen - Oxfordien supérieur dans le Sud-Est du Bassin de Paris. Bulletin de la Society Géologique de France, 175, 289-302.

Mamet, B. \& Préat, A. 2006. Jurassic microfacies, Rosso Ammonitico limestone, Subbetic Cordillera, Spain. Revista Española de Micropaleontología, 38, 219-228.

Mandernack, K.W. \& Tebo, B.M. 1993. Manganese scavenging and oxidation at hydrothermal vents and in vent plumes. Geochimica et Cosmochimica Acta, 57, 3907-3923.

Marques, B., Olóriz, F. \& Rodríguez-Tovar, F.J. 1991. Interactions between tectonics and eustasy during the Upper Jurassic and lowermost Cretaceous. Examples from the south of Iberia. Bulletin de la Societé Géologique de France, 162, 1109-1124.

Martín-Algarra, A. \& Sánchez-Navas, A. 1995. Phosphate stromatolites from condensed cephalopod limestones, Upper Jurassic, Southern Spain. Sedimentology, 42, 893-919.

Martín-Algarra, A. \& Sánchez-Navas, A. 2000. Bacterially mediated authigenesis in Mesozoic stromatolites from condensed pelagic sediments (Betic Cordillera, Southern Spain). SEPM Special Publication, 66, 499-525.

Martín-Algarra, A. \& Vera, J.A., 1994. Mesozoic pelagic phosphate stromatolites from the Penibetic (Betic Cor- 
dillera Southern Spain). In: Phanerozoic Stromatolites II (Eds. J. Bertrand-Sarfati \& C. Monty). Kluwer Academic Publishers, 345-391.

Matsumoto, R., Minai, Y. \& Iijima, A. 1985. Manganese content, Cerium anomaly, and rate of sedimentation as clues to characterize and classify deep sea sediments. In: Advances in Earth and Planetary sciences, Formation of Oceanic Margin (Ed. N. Nasu). Terra Science Publications, Tokyo, 913-939.

McDonough, W.F. \& Sun, S.S. 1995. The composition of the Earth. Chemical Geology, 120, 223-253.

Meléndez, G., Ramajo, J. \& Martínez-Cotanda, S. 2005. El desarrollo de la Capa de Arroyofrío (límite CallovienseOxfordiense) al Sur de Zaragoza, entre Ricla y Aguilón: bioestratigrafía y facies. Geogaceta, 38, 3-6.

Mills, R.A. \& Eldefield, H. 1995. Rare earth element geochemistry of hydrothermal deposits from the active TAG mound, $26^{\circ} \mathrm{N}$ Mid-Atlantic Ridge. Geochimica et Cosmochimica Acta, 59, 3511-3524.

Mišík, M. \& Aubrecht, R. 2004. Some notes concerning mineralized hardgrounds (Jurassic and Cretaceous, Western Carpathians). Were all hardgrounds always hard from the beginning? Slovak Geologic Magazine, 10, 183-202.

Molina, J.M. 1987. Análisis de facies del Mesozoico en el Subbético Externo (Provincia de Córdoba y Sur de Jaén). PhD Thesis Universidad de Granada, 518 pp.

Molina, J.M., Ruiz-Ortiz, P.A. \& Vera, J.A. 1995. Neptunian dykes and associated features in southern Spain: mechanisms of formation and tectonic implications. Discussion. Sedimentology, 42, 957-960.

Molina, J.M., Ruiz-Ortiz, P.A. \& Vera, J.A. 1999. A review of polyphase karstification in extensional tectonic regimes: Jurassic and Cretaceous examples, Betic Cordillera, southern Spain. Sedimentary Geology, 129, 71-84.

Monty, C. 1984. Cavity and fissure dwelling stromatolites (endostromatolites) from Belgian Devonian mud mounds. Annales Société Géologique Belgique, 105, 343-344.

Myrow, P.M. \& Coniglio, M. 1991. Origin and diagenesis of cryptobiontic Frutexites in the Chapel Island Formation (Vendian to Early Cambrian) of southeast Newfoundland, Canada. Palaios, 6, 572-585.

Nealson, K.H. 1983. The microbial iron cycle. In: Microbial geochemistry (Ed. W.E. Krumbein). Blackwell Scientific Publications, Oxford, 159-190.

Nealson, K.H. \& Stahl, D.A. 1997. Microorganisms and biochemical cycles: What can we learn from layered microbial communities? Reviews in Mineralogy, 35, 5-34.

Nicoll, R.S. \& Playford, P.E. 1993. Upper Devonian iridium anomalies, conodont zonation and the Frasnian-Fammenian boundary in the Canning Basin, Western Australia. Palaeogeography, Palaeoclimatology, Palaeoecology, 104, 105-113.

Nieto, L.M. 1997. La cuenca subbética mesozoica en el sector oriental de las Cordilleras Béticas. PhD Thesis Universidad de Granada, 562 pp.

Nose, M., Schmid, D.U. \& Leinfelder, R.R. 2006. Significance of microbialites, calcimicrobes, and calcareous algae in reefal framework formation from the Silurian of Gotland, Sweden. Sedimentary Geology, 192, 243-265.

O’Dogherty, L., Sandoval, J. \& Vera, J.A. 2000. Ammonite faunal turnover tracing sea level changes during the Jurassic (Betic Cordillera, southern Spain). Journal of the Geological Society London, 157, 723-736.

O’Dogherty, L., Martín-Algarra, A., Gursky, H.J. \& Aguado, R. 2001. The Middle Jurassic radiolarites and the pelagic limestones of the Nieves Unit (Rondaide Complex, Betic Cordillera): basin starvation in a rifted marginal slope of the western Tethys. International Journal of Earth Sciences, 90, 831-846.

Olivier, N. 2004. Microbialites dans les bioconstructions $d u$ Jurassique: morphologies, rôles edificateurs et significations paléoenvironnementales. $\mathrm{PhD}$ Thesis Université Claude-Bernard Lyon 1, Lyon, 380 pp.

Olóriz, F., Reolid, M. \& Rodríguez-Tovar, F.J. 2002. Fossil assemblages, lithofacies and taphofacies for interpreting depositional dynamics in epicontinental Oxfordian (Prebetic Zone, Betic Cordillera, southern Spain). Palaeogeography, Palaeoclimatology, Palaeoecology, 185, 53-75.

Olóriz, F., Reolid, M. \& Rodríguez-Tovar, F.J. 2004. Taphonomy of ammonite assemblages from the Middle-Upper Oxfordian (Transversarium?-Bifurcatus Zones) in the Internal Prebetic (Betic Cordillera, Southern Spain): Taphonic populations and taphofacies for ecostratigraphic interpretations. Rivista Italiana di Paleontologia e Stratigraphia, 110, 239-248.

Ostwald, J. 1990. The biochemical origin of the Groote Eylandts manganese oxide pisoliths and ooliths, Northern Australia. Ore Geology Reviews, 5, 469-490.

Palma, R.M. \& Angeleri, M.P. 1992. Early Cretaceous serpulid limestones: Chachao Formation, Neuquen Basin, Argentina. Facies, 27, 175-178.

Peck, S.B. 1986. Bacterial deposition of iron and manganese oxides in North American caves. National Association of Speleologists Bulletin, 48, 26-30.

Perri, E. \& Tucker, M. 2007. Bacterial fossils and microbial dolomite in Triassic stromatolites. Geology, 35, 207-210.

Playford, P.E., Cockbain, A.E., Druce, E.C. \& Wray, J.L. 1976. Devonian stromatolites from the Canning Basin, Western Australia. In: Stromatolites (Ed. M.R. Walter). Developments in Sedimentology, 20, Elsevier, Amsterdam, 543-563.

Playford, P.E., McLaren, D.J., Orth, C., Gilmore, J.S. \& Goodfellow, W.D. 1984. Iridium anomaly in the Upper Devonian of the Canning Basin, Western Australia. Science, 226, 437-439.

Préat, A., Mamet, B., Di Stefano, P., Martire, L. \& Kolo, K. 2011. Microbially-induced Fe and Mn oxides in condensed pelagic sediments (Middle-Upper Jurassic, Western Sicily). Sedimentary Geology, 237, 179-188.

Puga, E., Portugal, M., Díaz de Federico, A., Bargossi, G.M. \& Morten, L. 1989. The evolution of the magmatism in the external zones of the Betic Cordilleras during the Mesozoic. Geodinamica Acta, 3, 253-266.

Ramajo, J. \& Aurell, M., 1997. Análisis sedimentológico de las discontinuidades y depósitos del Calloviense superior- 
Oxfordiense medio en la Cordillera Ibérica Noroccidental. Cuaderno de Geología Ibérica, 22, 213-236.

Ramajo, J., Aurell, M. \& Cepría, J. 2002. Análisis de facies de la Capa de oolitos ferruginosos de Arroyofrío en la Sierra de Arcos (Jurásico, Cordillera Ibérica septentrional). Journal of Iberian Geology, 28, 45-64.

Rankama, K. \& Sahama, T.G. 1960. Geochemistry. University of Chicago Press, Chicago, 912 pp.

Reitner, J., Thiel, V., Zankl, H., Michaelis, W., Wörheide, G. \& Gautret, P. 2000. Organic and biogeochemical patterns in cryptic microbialites In: Microbial Sediments (Eds. R. Riding \& S.M. Awramik). Springer, Berlin, 149-160.

Reolid, M. 2007. Taphonomy of the Oxfordian-Lowermost Kimmeridgian Siliceous Sponges of the Prebetic Zone (Southern Iberia). Journal of Taphonomy, 5, 71-90.

Reolid, M., Abad, I. \& Martín-García, J.M. 2008. Palaeoenvironmental implications of ferruginous deposits related to a Middle-Upper Jurassic discontinuity (Prebetic Zone, Betic Cordillera, Southern Spain). Sedimentary Geology, 203, 1-16.

Reolid, M. \& Gaillard, C. 2007. Microtaphonomy of bioclasts and paleoecology of microencrusters from Upper Jurassic spongiolithic limestones (External Prebetic, Southern Spain). Facies, 53, 97-112.

Reolid, M., Gaillard, C., Olóriz, F. \& Rodríguez-Tovar, F.J. 2005. Microbial encrustation from the Middle Oxfordianearliest Kimmeridgian lithofacies in the Prebetic Zone (Betic Cordillera, southern Spain): characterization, distribution and controlling factors. Facies, 50, 529-543.

Reolid, M. \& Molina, J.M. 2010. Serpulid-Frutexites assemblage from shadow-cryptic environments in Jurassic marine caves (Betic Cordillera, South Spain). Palaios, 25, 468-474.

Reolid, M. \& Nieto, L.M. 2010. Jurassic Fe-Mn macrooncoids from pelagic swells of the External Subbetic (Spain): evidences of microbial origin. Geologica Acta, 8, 151-168.

Reolid, M., Nieto, L.M. \& Rey, J. 2010. Taphonomy of cephalopod assemblages from Middle Jurassic hardgrounds of pelagic swells (South-Iberian Palaeomargin, Western Tethys). Palaeogeography, Palaeoclimatology, Palaeoecology, 292, 257-271.

Reolid, M., El Kadiri, K., Abad, I., Olóriz, F. \& Jiménez-Millán, J. 2011. Jurassic microbial communities in hydrothermal manganese crust from the Rifian Calcareous Chain, Northern Morocco. Sedimentary Geology, 233, 159-172.

Rey, J. 1993. Análisis de la Cuenca Subbética durante el Jurásico y el Cretácico en la transversal Caravaca-Vélez Rubio. PhD Thesis Universidad de Granada, 460 pp.

Riding, R. 1991. Calcified Cyanobacteria. In: Calcareous algae and stromatolites (Ed. R. Riding). Springer, Berlin, 21-51.

Rodríguez-Martínez, M., Heim, C., Simon, K., Zilla, T. \& Reitner, J. 2011. Tolypammina vagans Wendt 1969 - Frutexites assemblage and ferromanganese crust: a coupled nutrient-metal interplay in the Carnian sedimentary condensed record of Hallstatt Facies (Austria). Lecture Notes in Earth Sciences, 131, 409-434.
Rojkovič, I., Aubrecht, R. \& Mišik, M. 2003. Mineral and chemical composition of manganese hardgrounds in Jurassic limestones of the Western Carpathians. Geologica Carpathica, 54, 317-328.

Sageman, B.B., Wignall, P.B. \& Kauffmann, E.G. 1991. Biofacies models for oxygen-deficient facies in epicontinental seas: tool for paleoenvironmental analysis. In: Cycles and Events Stratigraphy (Eds. G. Einsele, W. Ricken \& A. Seilacher). Springer, Berlin, 542-564.

Sandoval, J. 1983. Bioestratigrafía y Paleontología (Stephanocerataceae y Perisphinctaceae) del Bajocense y Bathonense en las Cordilleras Béticas. PhD Thesis Universidad Granada, 613 pp.

Santelli, C.M. 2009. Life in the deep sea. Nature Geoscience, 2, 825-826.

Schaefer, M.O., Gutzmer, J. \& Beukes, N.J. 2001. Late Paleoproterozoic Mn-rich oncoids: Earliest evidence for microbially mediated Mn precipitation. Geology, 29, 835-838.

Schlögl, J., Michalík, J., Zágoršek, A. \& Atrops, F. 2008. Early Tithonian serpulid-dominated cavity-dwelling fauna and the recruitment pattern of the serpulid larvae. Journal of Paleontology, 82, 382-392.

Scouflaire, Q., Marchand, D., Bonnot, A., Courville, P., Raffray, M. \& Huault, V. 1997. Le contact CallovienOxfordien dans les environs de Chaignay: nouvelles données stratigraphiques et paléontologiques. Bulletin Science Bourgogne, 49, 45-63.

Sequeiros, L. 1974. Paleobiogeografía del Calloviense y el Oxfordiense en el sector central de la Zona Subbética. PhD Thesis Universidad de Granada, 2 vols, 262+371 pp.

Sequeiros, L. 1987. Caracterización cuali-cuantitativa del Calloviense de Cabra (Cordillera Bética, España). Boletín de la Real Sociedad Española de Historia Natural (Geología), 83, 25-46.

Seyfried, H. 1978. Der Subbetische Jura von Murcia (SudostSpanien). Geologisches Jahrbuch, 29, 3-204.

Soussi, M. \& M'rabet, A. 1991. Les faciès à oolithes ferrugineuses ('oolitic ironstones') du Jurassique moyen de l'Axe Nord-Sud (Tunisie centrale): caractéristiques et significations. Notes des Services Géologiques Tunisie, 57, 71-85.

Southam, G. 2000. Bacterial surface-mediated mineral formation. In: Environmental microbe-mineral interactions (Ed. D.R. Lovley). ASM Press, Washington DC, 257-276.

Taylor, S.R. \& McLennan, S.M. 1985. The Continental Crust: its Composition and Evolution. Blackwell Scientific, Oxford, $312 \mathrm{pp}$

Templeton, A.S., Knowles, E.J. Eldridge, D.L., Arey, B.W., Dohnalkova, A.C., Webb, S.M., Bailey, B.E., Tebo, B.M. \& Staudigel, H. 2009. A seafloor microbial biome hosted within incipient ferromanganese crusts. Nature Geosciences, 2, 872-876.

Toscano, F. \& Raspini, A. 2005. Epilithozoan fauna associated with ferromanganese crustgrounds on the continental slope segment between Capri and Li Galli Islands (Bay of Salerno, Northern Tyrrhenian Sea, Italy). Facies, 50, $427-441$. 
Usui, A., Bau, M., \& Yamazaki, T. 1997. Manganese microchimneys buried in the Central Pacific pelagic sediments: evidence of intraplate water circulation? Marine Geology, 141, 269-285.

Veillette, J., Juniper, S.K., Gooday, A.J. \& Sarrazin, J. 2007. Influence of surface texture and microhabitat heterogeneity in structuring nodule faunal communities. Deep-Sea Research I, 54, 1936-1943.

Vera, J.A. 2001. Evolution of the Iberian Continental Margin. Mémoires du Muséum National d'Histoire Naturel de Paris, 186, 109-143.

Vera, J.A., Molina, J.M., Montero, P. \& Bea, F. 1997. Jurassic guyots in the Southern Iberian Continental Margin: a model of isolated carbonate platforms on volcanic submarine edifices. Terra Nova, 9, 163-166.
Vera, J.A., Martín-Algarra, A., Sánchez-Gómez, M., Fornós, J.J. \& Gelabert, B. 2004. Cordillera Bética y Baleares. In: Geología de España. (Ed. J.A. Vera). SGE-IGME, Madrid, 347-464.

Wallace, M.W., Keays, R.R. \& Gostin, V.A. 1991. Stromatolitic iron oxides: evidence that sea-level changes can cause sedimentary iridium anomalies. Geology, 19, 551-554.

Walter, M.R. \& Awramik, S.M. 1979. Frutexites from stromatolites of the Gunflint Iron Formation of Canada, and its biological affinities. Precambrian Research, 9, 23-33.

Ziegler, P.A. 1988. Evolution of the Arctic-North Atlantic and the Western Tethys. American Association of Petroleum Geologists Memoir, 43, 198 pp.

Manuscrito recibido: 16 de septiembre, 2011 Manuscrito aceptado: 16 de noviembre, 2011 